Dokuz. Eylül Üniversitesi

İlabiyat Fakeültesi Dergisi

2014/2, Sayn 40, ss. 33-68.

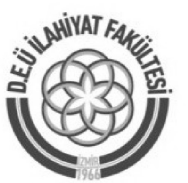

\title{
SÜLEYMAN ATEŞ VE W. CANTWELL SMİTH'E GÖRE EHLİ KİTAB (HIRİSTIYYANLAR)'IN VE MÜSLÜMANLARIN KURTULUŞU
}

Muammer ERBAŞ*

\section{ÖZET}

Tarih boyunca geleneksel dini anlayışların birbirine bakışı, büyük ölçüde olumsuz ve dışlayıcı olmuştur. Bununla birlikte modern dönemde başlayan Hıristiyan - Müslüman iletişim ve ilişkileri, bu yaklaşım tarzlarının bugün için büyük ölçüde yetersiz kaldığını göstermiştir. Bu bağlamda 1lımlı Doğulu ve Batı'lı din araştırmacıları, her iki kesimi birden tatmin edip uzlaştırmaya yönelik yeni yaklaşım tarzları geliştirme çabası içine girmiştir. Bunların en önemlilerinden ikisi olan Süleyman Ateş ve W. Cantwell Smith, Hıristiyanlık ile İslam arasında geleneksel bakış açılarını eleştirip bir yana bırakan yeni yaklaşım tarzları geliştirmiş ve her iki din arasında bunlara dayalı karşılaştırmalar yapmıştır. Onlar, çalışmalarında farklı yöntemler kullanmakla birlikte hem Ehli Kitab (Hıristiyanlar), hem de Müslümanlar için kurtuluşun kendi kutsal kitapları ve dini gelenekleri içinde mümkün olduğu sonucunda birleşmişlerdir. $\mathrm{Bu}$ aşamada her iki kesimi birden ikna etmekten ziyade büyük ölçüde rahatsız eden bu yeni yaklaşım tarzları, en azından Hıristiyan ve Müslüman kesimlerin birbirini doğru anlamasına katkı sağlaması ve daha sonra yapılacak tarafsız araştırmalara öncülük etmesi itibarıla belli ölçüde değer ve anlam taşımaktadır.

Anahtar Kelimeler: Ehli Kitab, Hiristiyan, Müslüman, Tevrat, İncil, Kur’an, Kurtuluş.

\section{THE SALVATION OF THE PEOPLE OF THE BOOK (CHRISTIANS) AND MUSLIMS: A COMPARISON OF SULEYMAN ATES AND WILFRED CANTWELL SMITH \\ ABSTRACT}

Throughout the history the view of religious traditions to each other has been largely negative and exclusionary. However, by the beginning of the modern era, Christian Muslim communications and relationships make this approaches largely ineffective. In this context, moderate Eastern and Western religios scholars started to devise satisfiying approaches to compromise the two parties. Two of the most important of these scholars are Suleyman Ates and W. Cantwell Smith, who have made comparisons which critizes the traditional perspectives between Christianity and Islam. They have used different methods in their studies, but have reached the same conclusion that the salvation is possible for both of the People of the Book (the Christians) and the Muslims within their sacred books and in their religious traditions. At this stage, their approaches to some extent disturbed both sides rather than trying to persuade.

* Prof. Dr., Dokuz Eylül Üniversitesi İlahiyat Fakültesi Öğretim Üyesi 
Nevertheless these new approaches have great value since they contribute to the Christian and Muslim groups to understand each other correctly and lead future objective researches.

Keywords: The People of the Book, Christian, Muslim, Torah, Bible, Quran, Salvation.

Kur'an-1 Kerim nazil olmaya başladığında Müslümanlar, Arap yarımadasında müşrikler ve Yahudilerle birlikte Hiristiyanlarla da muhatap olmuşlardır. ${ }^{1}$ İlahi vahiy geleneğine uygun olarak tedrici bir șekilde nazil olan Kur'an ayetleri, genelde Ehli Kitab, özelde Hiristiyanlar hakkında indirgemeci ve toptancı bir yaklaşım sergilemek yerine muhatap olunan kesimlerin durumuna göre farklı bir üslub ve içerik arzetmiştir.

Başlangıçta Müslümanların Hıristiyanlarla ilişkileri, Habeş Necaşisi Ashame'nin gerek Habeşistan'a göç edenleri himaye etmesi, gerekse daha sonra kendisine gönderilen davet mektubuna olumlu karşılık vermesiyle gayet sıcak başlamıştır. Bununla birlikte son dönemde ortaya çıkan olumsuz gelişmeler, bu ilişkileri tamamen bozmuştur. Şöyle ki Hz. Peygamber, Gassani Kralı Hâris b. Ebû Şemir'e elçi olarak Şücâ' b. Ebû Vehb el-Esedi'yi göndermiş, fakat bu kral mektubu alır almaz yırtmıştır. ${ }^{2}$ Benzer şekilde Hz. Peygamber, Haris b. Umeyr’i Busra valisine göndermiş, elçi yolda Gassani emirlerinden Şurahbil b. Amr tarafindan tutuklanıp şehid edilmiştir. Bunun üzerine Hz. Peygamber, önce Hıristiyan olan Gassaniler üzerine Mute'ye Zeyd b. Harise komutasında bir ordu yollamış, ardından da bizzat kendisi Tebuk seferini düzenlemiştir. Doğal olarak bu gelişmeler üzerine nazil olan ayetlerdeki üslup ve içerik çok sert olmuștur: "Kendilerine Kitap verilenlerden Allah'a ve abiret gününe inanmayan, Allah ve Resûlïnün haram kildiğmn haram saymayan ve hak dini kendine din edinmeyen kimselerle, kücülerek elleriyle cizye verinceye kadar savaşin."

Bu noktada geleneksel İslam anlayışında, haklarında Kur'an'da sergilenen farklı yaklaşımlar büyük ölçüde göz ardı edilmek suretiyle Yahudisi ve Hıristiyanıyla bütün Ehli Kitap aynı kefeye konmuş, onlar hakkında nazil olan olumlu ayetler bütünüyle mensuh sayılmış ve son ayetlerde yer alan sert hükümler esas alınmak suretiyle bütün Ehli Kitab hakkında kendilerini aşağılayarak cizye almaya dayalı standart bir bakış açısı geliştirilmiştir. ${ }^{4}$ Ardından Hiristiyanlarla ile Müslümanlar arasında, tarihte Haçlı seferleri olarak bilinen ve asırlarca devam eden fiili savaş dönemi yaşanmıştır. Bunun da etkisiyle ortaya

1 Geniş bilgi için bkz. Sönmez, Zekiye, İslam'ın Ortaya Cıktı̆ğ Dönemde Arap Yarmadasında Hiristiyanllk, Ankara 2012, s. 26-87.

2 İbn Sa'd, Ebu Abdullah, et-Tabakatü'-Kübra, Beyrut tz, I, 261.

3 Tevbe 9/29, 123. (Bkz. et-Taberi, Muhammed b. Cerir, Camiu'l-Beyan an Te'vili Ayi'l-Kur'an, Kahire 1955-1969, X, 106; XI, 71; el-Kurtubi, Ebu Abdullah, el-Cami' li Abkami'l-Kur'an, Beyrut 1965, VIII, 297.

4 Bkz. Erkal, Mehmet, "Cizye”, Diyanet İslam Ansiklopedisi, İstanbul 1993, VIII, $42-45$. 
çıkan Hıristiyanlığa dair son derece olumsuz yaklaşım tarzı, adeta kemikleşmiş ve günümüze kadar değişmeden gelmiştir.

$\mathrm{Bu}$ durum, bilebildiğimiz kadarıyla Yahudisi ve Hıristiyanıyla Ehli Kitab'ın İslam'a ve Müslümanlara dair geleneksel bakış açısında çok daha vahim bir durum arzetmiştir. Zira buna göre Hz. Muhammed sahte bir peygamber olup, onun sağdaki soldaki haham, keşiş ve rahiplerden derleyip toparladığı Kur’an vahiy mahsulü bir Kitab, İslam Hak bir din, dolayısıyla da Müslümanlar ciddiye alınıp değer verilmesi gereken kimseler değildir. ${ }^{5}$

Birbirine zıt gibi gözüken bu iki geleneksel yaklaşımın ortak noktası, her ikisinin de tamamen önyarg1lı, indirgemeci ve insafsız olmasıdır. Uzun asırlar boyunca süren kutsal savaşlar ve bu uğurda can veren binlerce dindar insanın kanlarıla sulanıp beslenen kin ve nefrete dayalı bu geleneksel anlayışların oluşturduğu ağır mahalle baskısı altında, o günden bugüne ne Müslümanlar Ehli Kitab'ı tarafsız bir şekilde araştırıp anlamaya çalışmıs, ne de Ehl-i Kitab Müslümanlara samimi bir şekilde kulak verip onlara kendilerini ifade etme firsat ve imkanı tanımıştır. Bilakis bütün kesimler, şu ortak parolayı kendilerince tekrarlayıp durmuştur: "Yahudi/Hıristiyan/Müslïman) olmadıkşa, Cennet'e giremezsin." Buna aykırı herhangi bir söylem, sahibini acımasız bir şekilde aforoz mekanizmasının kurbanı kılmıştır.

Halbuki günümüze değin geçen ondört asır boyunca, köprünün altından çok sular akmıştır. Bugün itibarıyla karşımızda hem inanç ve düşünce, hem de eylem ve tutum yönünden ne dünkü Müslümanlık, ne de dünkü Ehli Kitab (Hıristiyanlık) mevcuttur. Müslümanlar açısından sahip oldukları tahkiki imanla geçmişteki dini olsun, dünyevi olsun her alanda öncü olan İslam toplumlarıla bugünün her yönden çok geri olan İslam alemi arasında büyük uçurum mevcuttur.

Hıristiyanlık açısından durum çok daha karışıktır. Zira ilk dönemlerde görülen firkalaşma bugün had safhaya ve uç noktalara ulaşmışıtı. Öyle ki bugün baz1 Katolikler, kendilerine Hiristiyan denmesinden rahatsızlık duyabilmektedir. Batı'nın farklı köşelerinde yükselen kiliselerden her biri, diğerinden tamamen kopuk bir şekilde ayrı bir düşünce, eylem ve tutum benimsemiştir. Bunun ötesinde bir kimse, kendi cemaatini kurabilmekte ve bütün diğerlerinden bağımsız olarak hareket edebilmektedir. Dolayısıyla bugün için karşımızda inanç olarak teslisi kabul etmeyenlerden ${ }^{6}$ Kur'an'1 Allah kelamı Hz. Muhammed'i de

5 "Süphesiz, biz onlarn: «Kur'an'ı ona ancak bir insan ögretiyor» dediklerini biliyoru₹: Kendisine nisbet ettikleri șabsin dili yabancıdrr. Halbuki bu (Kur'an) apaçk bir Arapsader." (Nahl 16/103) (Bkz. İbn Kesir, İsmail b. Kesir, Tefsiru'l-Kur'ani'l-Azim, İstanbul 1985, IV, 523)

6 Bkz. Vitray-Meyerovitch, Eva de, İslam'in Güler Yüzü, (Çev. Cemal Aydın), İstanbul 1999, s. 58-vd, 149-vd.) 
bir peygamber olarak görenlere, ${ }^{7}$ yaşam tarzı olarak eşcinsel evliliği benimseyip savunan papazlardan, ${ }^{8}$ binlerce Hıristiyan önünden domuz eti ve içkinin zarar ve sakıncalarını anlatanına ${ }^{9}$ varıncaya kadar onlarca farklı Yahudi ve Hıristiyan kesim mevcuttur.

Bu örnekler, bizlere, bütün Ehli Kitab'ın gerek kendi dinleri, gerekse birbirleri hakkında aynı görüş ve yaklaşımları paylaşmadığı, dolayısıyla bunların her birini resmi otorite ve temsilcilerinden bağımsız olarak kendi bütünlükleri içinde ayrı ayrı incelemek gerektiğini göstermektedir. Bu durumda Müslümanlar ile Hıristiyanların geçmişte birbirleri hakkında verdiği hükümlerin çoğu, bugün itibarıyla havada kalmakta, gerçek hayatta karşlığını bulmamaktadır.

$\mathrm{Bu}$ noktada ümit verici olan husus, gerek Müslümanlar gerekse Hıristiyanlar içinde mevcut durumun yanlışlığını anlayan ve bunu aşmak için alternatif bakış açıları geliştirmeye çalışan ilim adamlarının ortaya çıkmaya başlamasıdır. Büyük bir mahalle baskısı altında aforoz edilmeyi göz önüne alan bu kimseler, binlerce Müslüman ve Hiristiyanın iç içe yaşadığ1 günümüz dünyasında onların birbirlerine karşı daha sağlıklı bir iliş̧i ve iletişim tarzı içine girebilmesi için uygun zemin hazırlamaya çalışmaktadırlar.

Biz, bu çalışmamızda onlardan ikisinin görüş ve yaklaşımlarını karşılaştırmalı olarak ele alıp incelemeye çalışacağız. Bunlardan ilki, Türkiye'de 1950’lerde açılan İlahiyat Fakültelerinin önce ilk öğrencilerinden, sonra da ilk hocalarından biri olan Süleyman Ateş'tir. O, bilhassa tefsir alanında yaptığı çalışmalarla İlahiyat literatürüne büyük katkıda bulunmuş önemli bir ilim adamıdır. Sayın Ateş, 1989 yılında kaleme aldığ " "Cennet Kimsenin Tekelinde Değildir!" isimli makalesinde ${ }^{10}$ ve daha sonra yazdığı on ciltlik "Yüce Kur'an'ın Çağdaş Tefsiri" isimli tefsirinde, ${ }^{11}$ Ehli Kitab hakkındaki geleneksel İslami yaklaşım tarzını eleştirmiş, bunun yerine günümüze daha uygun düşecek Kur'an'a dayalı yeni bir bakış açısı geliştirmeye çalışmışıır.

Çalışmamızda görüşlerine yer vereceğimiz ikinci ilim adamı, Batı'lı çağdaş şarkiyatçların en önemli ve meşhurlarından biri olan W. Cantwell Smith

7 Avrupa Kiliseler Birliği, 5 -10 Mart 1984 tarihleri arasında Avusturya'nın Pölten Şehri'nde gerçekleștirdiği konferansta, şu karar yer almıştır: "Bu toplantıda Kuran'ın Allah Kelâmı ve Hz. Muhammed'in ise Hz. İbrahim'den beri gelen Peygamberler zincirinin bir halkas1 olduğunu ve asla sahte peygamber olamayacağını itiraf ettik." (Bkz. Akgündüz, Ahmet, Can'dan Minare'ye Büyüle İtiraf, İstanbul 2010; http://video.haber7.com/play.video.php?id=5765)

8 Http://webtv.hurriyet.com.tr/2/18527/0/1/italya-kilise-de-ilk-escinsel-evlilik.aspx.

9 Osteen, Joel, “The Meat of His Pork Message", YouTube Videos.

10 Ateş, Süleyman, “Cennet Kimsenin Tekelinde Değildir”, İslami Araștırmalar, Cilt 3, Sayı 1, s. 7-24, Ankara Ocak 1989.

11 Ateş, Süleyman, Yüce Kur'an'in Çă̆daş Tefsiri, İstanbul 1991, I-XII. 
(ö.2000)'dir. Karşılaştırmalı Din alanında çok sayıda eser kaleme alan W. Cantwell Smith, yazdığı eserlerde İslam'a yönelik geleneksel oryantalist bakış açısını eleştirmek suretiyle ortaya İslam ile Hıristiyanlı arasında birbirini anlamaya yönelik mutedil yaklaşımlar ortaya koymuş, bu sayede en az Hıristiyan alemi kadar İslam aleminin de dikkatini çekmiş ve takdirini kazanmıştır. Biz, bu çalışmamızda, daha ziyade onun "On Understanding Islam" isimli derleme eserinden ${ }^{12}$ istifade edeceğiz.

Çalışmamızın hemen başında belirtmeliyiz ki, Ehli Kitab'ın ve Müslümanların kurtuluşu konusunda S. Ateş ile W.C. Smith farklı noktalardan hareket etmekte, farklı kavram ve yöntemleri kullanmakta, fakat sonuçta benzer şeyleri söylemekte ve ortak bir noktada buluşmaktadır. Bu konuda birbirleriyle görüş alısverişinde bulunup bulunmadıklarını bilememekle birlikte her ikisinin de, son dönemde dünya çapinda ön plana çıkan Ehli Kitab-Müslüman diyaloğuna olumlu anlamda katkıda bulunma hususunda ortak bir eğilime sahip olduklarını görüyoruz.

Bu hususta Süleyman Ateş, meseleyi daha ziyade Kur'an çerçevesinde ve Ehli Kitab genelinde ele alırken, W. Cantwell Smith konuya rasyonel bilimsel yaklaşımlar çerçevesinde, fakat Hıristiyanlık özelinde yaklaşmaktadır.

Biz, bu çalışmada yöntem olarak ele aldıkları hususlar birebir örtüşmediği için düşünce bütünlügünün bozulmaması amacıyla üç ayrı başlık altında sırasıyla önce Süleyman Ateş'in görüşlerine, ardından da W. Cantwell Smith'in görüşlerine yer vereceğiz. Gerekli gördüğümüz yerlerde kendi görüş ve eleştirilerimizi dipnotlarda zikredecek, çalışmanın sonunda da kısa bir değerlendirmede bulunacağız.

\section{A. TARİHİ PERSPEKTİFTEN EHLİ KİTAB (HRİSTİYANLIK) ÍLE İSLAM'IN BİRBİRLERİNE GÖRE KONUMU:}

Süleyman Ateş, konuya kronolojik tarihi gelişim sürecinden ziyade kendi uzmanlık alanı olan Kur'an'a dayalı tarihi perspektif içinde bakar. Ona göre İslam, yalnız Allah'a tapmak, ibadeti yalnız Ona özgü kılmaktır. Bu anlamda bütün peygamberler İslam'ı getirmiştir. Nitekim Kur'an'da İslam kelimesi, yalnız $\mathrm{Hz}$. Muhammed'in getirdiği din için değil, bütün peygamberlerin getirdiği ortak din için kullanılmıştır. Çünkü peygamberlere verilen mesajın mahiyeti aynıdır. Onların hepsi, insanları tek Allah'a kulluğa, ahirete imana ve salih amele davet etmiştir. Bu bakımdan misyonları aynı olan peygamberler arasında bir ayırım yapilamaz: "Allab'in elçileri arasında bir ayırm yapmayı:"13

12 Smith, Wilfred Cantwell, On Understanding Islam (Selected Studies), The Hague, The Netherlands 1981

13 Bakara 2/285. (Bkz. Ateş, Süleyman, Çağdaş Tefsir, XI, 336-vd.) 
S. Ateş, Allah Teala'nın ilk elçisi olan Hz. Nuh'a neyi vahyetmişse, son elçisi olan Hz. Muhammed'e de onu vahyettiğini söyler. ${ }^{14}$ Ona göre şu ayetler, bütün peygamberlerin Müslüman olup İslam'1 getirdiklerini bildirmektedir: 'Rabbi ona (Íbrabim'e); 'İslam ol!' demiști. 'Alemlerin Rabbine teslim oldum,' dedi. İbrahim de bunu kendi oğullarna vasiyet etti. Yakub da; 'Oğullarm, Allah siz̨in için o dini sectt, bundan dolayn sadece Müslümanlar olarak ölünüz!' (dedi). Yoksa siz, Yakub’a ölüm (bali) geldiği zaman orada mo idiniz? O zaman (Yakub), oğullarna; 'Benden sonra neye kulluk edeceksiniz?' demisti. 'Senin tanrin ve atalarn İbrabim, İsmail ve İshak'in tanrss olan tek Tanriya kulluk edeceğiz, biz Ona teslim olanları!' dediler."15

S. Ateş, Hz. İsa'ya verilen İncil'in İslam'1 içerdiği gibi, ona inanan havarilerin de Müslüman olduklarını söyler: "Havarilere; 'Bana ve elçime inann?

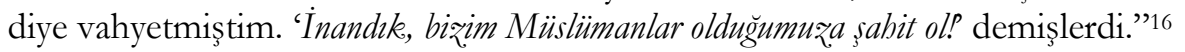

$\mathrm{Bu}$ noktada son peygamber olarak Hz. Peygamber'in yeni bir din icadetme gayesiyle değil, Hz. İbrahim'in getirdiği tevhid dinini asli safiyetine kavuşturmak için gönderildiğini belirten S. Ateş, onun misyonunun öncekileri kendisine tabi kilmak olmayıp, bilakis Hz. İbrahim'e ve onun soyundan gelen peygamberlere uymak olduğunu ifade eder: "De ki: Ben, elçiler içinde bir türedi değilim (peygamberliği ille defa ben ortaya atmadim, önceki peygamberlerin söylemedikleri bir seyi söyleyen bir elçi değilim); bana ve size ne yapulacağgm da bilmem. Ben, sadece bana vabyedilene uyuyorum." 17

S. Ateş'e göre, Hz. Peygamber'in getirdiği din yeni değil, atası Hz. İbrahim'in bildirdiği İslam olduğu gibi, Yahudilik ve Hıristiyanlık da asli hüviyetleriyle Hz. İbrahim'in getirdiği tevhid dinidir: "Hangi insanm dini, ivilike edici olarak yüzünü Allah'a teslim edip dosdoğru İbrabim dinine tabi olanm dininden daha güzel olabilir? Allah, İbrahim'i dost edinmişsir."'s

S. Ateş, neticede Hz. Peygamber'in önceki peygamberler karşısındaki konumunun metbu; yani kendisine uyulan değil, tabi; yani kendisi onlara uyan olduğunu ifade eder. Nitekim Kur'an'da, Hz. İbrahim'den itibaren gönderilen İsrafiloğlu peygamberleri ve onların misyonları övgüyle zikredildikten sonra $\mathrm{Hz}$. Peygamber'den öncekilerin izinden gitmesi istenir: “... İste onlar, Allab'in bidayet ettigi kimselerdir. Sen de, onlarn yoluna uy..."19

\footnotetext{
“Bir, Nub'a ve ondan sonra gelen peygamberlere vabyettiğimiz gibi sana da vabyettik..." (Nisa 4/163)

Bakara 2/131-133.

16 Maide 5/112. (Bkz. Ateş, Süleyman, “Cennet Kimsenin Tekelinde Değildir”, s. 7-8)

17 Ahkaf 46/9. (Bkz. Ateş, Süleyman, Çăgdas Tefsir, VIII, 368, 370-371)

18 Nisa 4/125. (Bkz. Ateş, Süleyman, Căğdaş Tefsir, II, 372-375)

19 En'am 6/83-90. (Ateş, Süleyman, a.g.m., s. 9)
} 
S. Ateş, bu noktada Hz. Peygamber'in ilahi kitapların özünde aynı olan mesajlarını onun dilini anlamayan Arap milletine yeni bir ruh ile sunmuş olduğunu söyler. Ona göre art niyetten, kötü düşünceden ve bağnazlıktan uzak olan kimseler onun misyonunu engellemeye kalkmaz, bilakis kendisine yardımcı ve destek olurlar. Dolayısıyla bu noktada Ehli Kitab'a yaraşan yaklaşım tarzı, kendi kitaplarını destekleyen bu mesaja sahip çıkıp onunla aynı noktada

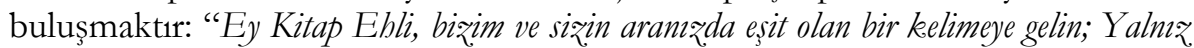
Allab'a tapalm, Ona biçbir şeyi ortak kossmayalim; birbirimizi, Allab'tan basska Rabler edinmeyelim!...'”o

Ona göre Ehli Kitab, Kur'an mesajını kendi kitaplarıyla arzettiği ortak içerikten dolayı daha ilk günden itibaren tanımıstır: "Kendilerine Kitap verdiğimiz kimseler, oğullarm tanudılar gibi o (Kur'an)' t tanrlar."21

Ehli Kitap içinden iyi yürekli olanlar, Kur'an vahyini işittiklerinde çok hislenmiş ve derhal ona iman etmişlerdir: "Onlar, Rasul'e indirilen (Kur'an'ı) dinledikleri zaman tanddklarn gerçekten dolay gözlerinin yaşla dolup taştığın görürsün. Derler ki; 'Rabbimiz, inandık bizi sabitlerle beraber yaz!' Biø, Rabbimizin, bizi iyiler arasina katmasin umarken neden Allab'a ve bize gelen gerçeğe inanmayalim!..."22

S. Ateş, Kur'an'da 'ilim verilenler' olarak nitelenen kimselerin hakperest Kitab ehli bilginleri olduğunu, bunların kendi dinlerinde yaşamaya devam etmekle birlikte -ki, bunu daha sonra ele alacağız- hem Kur'an'1, hem de Hz. Peygamber'i kabul ettiklerini söyler: 'De ki; 'Siæ, ister ona inann, ister inanmayn; o, daha önce kendilerine bilgi verilenlere (Kitap Eblinin alimlerine) okunduğu zaman onlar, derbal çeneleri üstüne secdeye kapanorlar. Rabbimiz̨in şam yücedir, gerçekten Rabbimižin söž̈ mutlaka yerine getirilir!' derler. Ağlayarak çeneleri üstüne kapanorlar ve Kur'an onlarn derin saygisin artırr.'”3

S. Ateş, bütün bu veriler 1şığında Kur'an’a göre bütün ilahi dinlerin özde bir ve bütün olduğunu, bunların gereğini yerine getiren Kitap Ehli kimselerin hep birlikte ebedi mutluluğa ereceğini ifade eder: "İnananlar, Yahudiler, Sabiiler ve Hiristiyanlar(dan) Allah'a ve abiret gününe inanan ve iyi işler yapanlara korku yoktur ve onlar ü̃ülmeyeceklerdir.'”24

S. Ateş, Kur'an'a dayalı olarak savunduğu bu hususları Hz. Peygamber’in sünnetiyle de destekler. Buna göre Hz. Peygamber, Hz. Musa’yı bütün insanlardan üstün gören bir Yahudi'yi bu yüzden tokatlayan bir sahabiye şunları söyler: “Allab'in peygamberlerini birbirinden üstün tutmayn. Cünkü sura üfleneceği gün

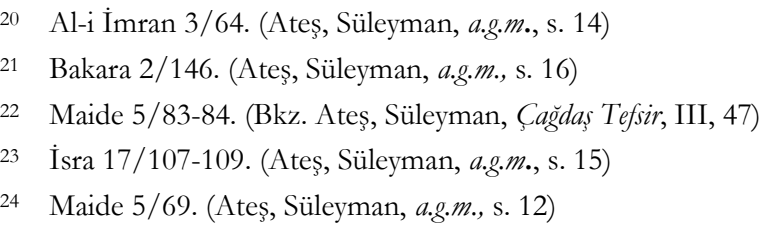


göktekilerin ve yerdekilerin hepsi helak olur, yalñ. Allah'ın dilediği kalır. Sonra tekrar sure üflenir, ben ilk dirilen olurum (veya ilk dirilenlerin arasinda bulunurum), bir de bakarm ki Musa, Arş̧ı(n kenarndan) tutmus. Artı. bilmem, Tur'da baynhp dïsmesiyle mi hesabr görülmüss (bundan dolayr mi artık. kiyamette baynlmamıs), yoksa o benden önce mi dirimis. Ben, kimsenin Matta oğlu Yunus'tan daha üstün olduğunu söyleyemem." 25

S. Ateş, benzer şekilde Hz. Peygamber'in Hz. İsa hakkında da şöyle buyurduğunu nakleder: "Ben, Meryem oğlu Isa'ya, dünyada da, abirette de insanlarn en yakmyym. Peygamberler, baba bir kardeşlerdir, anneleri ayrdir; dinleri birdir."26

S. Ateş'e göre Hz. Peygamber, bu sözlerini fili sünnetiyle de desteklemiştir. Şöyle ki o, Medine'ye geldiği zaman Yahudiler'in Aşure günü oruç tuttuklarını görüp onlara niye oruç tuttuklarını sormuş, onlar da Allah'ın Musa'yı ve kavmini Firavun ve kavminin zulmünden bu günde kurtardığını söyleyince şöyle buyurmuştur; 'Ben, Musa'ya siz̨den daha yakımım?' Bunun üzerine kendisi de oruç tutmuş ve ashabına o gün oruç tutmalarını emretmiştir. ${ }^{27}$

S. Ateş'in bu konuda naklettiği bir diğer rivayete göre, hicretin dokuzuncu yllında Necran Hıristiyanları'ndan altmış kişilik bir heyet Medine'ye gelir. Hz. Peygamber, onları kendi mescidinde ağırlar ve bir ay boyunca kendi usulleri üzere ibadet etmelerine müsaade eder. ${ }^{28}$

S. Ateş'e göre Kur'an ve sünnete ait bu yaklaşım tarzı Halifeler tarafindan da devam ettirilmiştir. Nitekim Hz. Ebu Bekr, sefere gönderdiği ilk ordunun komutanı olan Üsame'ye mabedlerinde kendilerini ibadete vermiş olan din adamlarına dokunmamalarını emretmisstir. Buna uygun olarak İslam hukukunda Kitap Ehline ayrıcalık tanınmak suretiyle onların kestiklerini yemek ve kızlarıyla evlenmek helal kilınmıştır. ${ }^{29}$

Netice itibarıyla S. Ateş, İslam'a göre tarihi perspektif itibarıly bütün peygamberler ve onlar tarafindan getirilen ilahi vahye dayalı mesajların öz itibarıly aynı olup, birbirlerini desteklediğini ifade eder. Fakat zaman içinde cehalet, kıskançlık ve menfaat uğruna bu İslam zincirinin halkaları birbirinden kopartılmış ve değişik adlarla etrafa saçılmıştır. Bu hususta her kesimin şu veya

25 el-Buhari, el-Camin's-Sahih, Enbiya, 35; el-Müslim, el-Camin's-Sabih, Fadail, 159.

26 el-Buhari, el-Camiu's-Sabih, Enbiya, 48; İbn Hişam, Ebu Muhammed, es-Siratü'n-Nebeviyye, Beyrut tz, II, 658.

27 el-Buhari, el-Camiu's-Sahih, Sıyam: Savmu Aşura, III, 96.

28 Hamidullah, Muhammed, İslâm Peygamberi, (Çev: Salih Tuğ), Ankara 2003, I, 920.

29 "Bugün size temiz ve iyi șeyler helâl kellnmuștır. Kendilerine kitap verilenlerin (yahudi, hıristiyan vb. nin) yiyeceği size helâldir, sižin yiyeceğiniz de onlara helaldir. Mümin kadinlardan iffetli olanlar ile daha önce kendilerine kitap verilenlerden iffetli kadinlar da, mebirlerini vermeniz, sartiyla, namuslu olmak, zina etmemek, ve gižli dost tutmamak üzere siz̨e helâldir...” (Maide 5/5) (Bkz. Ateş, Süleyman, a.g.m, s. 21-22) 
bu oranda hatası ve günahı olmakla birlikte, Ehli Kitab hakkında Kur'an ve sünnete bağlı bir müslümana yaraşan tavır, Kur'an'ın şu emrinden ayrilmamaktır: 'Ţ̧̧lerinde haksızlllk edenleri hariç, Kitap Ebliyle ancak en güzel tarzda mücadele edin ve; 'Bize indirilene de, size indirilene de inandlk; Tanrmız, ve Tanrmz birdir. Biz. de Ona teslim olanlarræ!' deyin." "30

W. Cantwell Smith, Hıristiyanlar ile Müslümanlar arasındaki ilişkilere kendisine özgü bir tarih perspektifi içinden bakar. O, öncelikle bunun bir çarpışma mı, karşılıklı ilişki mi, yoksa birbirine karışma mı olduğunu sorar. Ardından bu tarih hakkında ortaya dört farklı yaklaşım tarzı koyar:

a) İslam, Hıristiyanlığın dejenere olmuş halidir: Şam’lı John tarafından ortaya konan bu görüş, geleneksel Hıristiyan bakış açısıdır.

b) Hz. İsa, Hz. Adem ile başlayıp Hz. Muhammed ile sona eren uzun peygamberler silsilesinin önemli bir üyesidir: $\mathrm{Bu}$ da, geleneksel İslami bakış açısıdır. ${ }^{31}$

c) Hıristiyanlık bir din, İslam da başka bir dindir: $\mathrm{Bu}$, ondokuzuncu yüzyıla ait bakış açısıdır.

d) Mevcut durumu, dünya tarihine ait kavramlar 1şı̆̆ında, mevcut hassasiyetleri de göz önüne alarak günümüz bilgisi sşında yeniden formüle eden alternatif bir yaklaşım tarzı: Bu, W. Cantwell Smith'in bu çalışmada ulaşmayı hedeflediği şeydir. ${ }^{32}$

W. Cantwell Smith, bu iki dinin tarihini her ikisinin de iştirak ettiği daha üst kompleks bir yapının birbirinin yerine geçmiş farklı yüzleri olarak görmenin meseleyi anlamaya yardımcı olacağını söyler. Bunu aydınlığa kavuşturmak için daha önceye; Hiristiyan-Yahudi ilişkilerine gider. Ona göre dünyanın dini tarihi içinde Eski Ahit zamanlarında Filistin'de başlayıp modern Batı'nın dini yaşamına doğru hareket eden dini gelişim seyri, şu üç ana yoldan herhangi biriyle yorumlanabilir ki, bu üç farklı tefsir yönteminden herhangi birisinin seçimi, genellikle tarihe dayalı bir analizden ziyade dini bir ön kabule dayanır:

a) M.S. birinci yüzylla ulaşan Eski İsrail, bu tarihten sonra oradan yeni bir filiz olarak çıan Hiristiyan hareketiyle birlikte esas olarak Yahudilerin tarihi olarak devam etmiştir,

\footnotetext{
30 Ankebut 29/46. (Bkz. Ateş, Süleyman, Căğdaş Tefsir, VI, 517-518; XI, 336)

1 Yukarıda özetlediğimiz S. Ateş’e ait görüşler, bu yaklaşımın açılımı mahiyetindedir.

Smith, W. Cantwell, a.g.e, s. 248.
} 
b) Eski İsrail, M.S. birinci yüzylldan sonra bir filiz şeklinde sapkınlığa doğru giden Yahudilerle birlikte, esas olarak Hıristiyan Kilisesi olarak devam etmiştir: Bu, Ortadoks Hıristiyan bakış açısıdır.

c) Eski İsrail, M.S. birinci yüzyılda iki ayrı dala ayrılan bir çatallanma olarak devam etmiştir. Bunlardan her biri, daha önce olduğu gibi devam etmekle birlikte hem eskisinden, hem de birbirinden farklı iki dal şeklinde süregelmiştir.

W. Cantwell Smith'e göre, gerçek durum, bundan biraz daha karmaşıktır. Şöyle ki burada Sami dilini konuşan Doğu Kilisesi ve özellikle de İslam gerçeği dikkate alındığında, ortaya şu şekilde bir üçe ayrılma çıkmaktadır; Doğu, Batı ve Merkez.

Bu noktada W. Cantwell Smith, İslam dinini tarihi, statik, sabit müstakil bir oluşum olarak değil, bilakis hareket halindeki ilahi-insani bir kompleks yap1 olan İslami tarihe ait devam edegelen bir süreç, bunun da ötesinde insanllğın dini tarihi içinde İslami bir sahil/kıyı olarak görür. Ona göre Müslümanların kendi yaklaşımları içinde farkında oldukları bu gerçek, Hıristiyanlık için de geçerlidir. Şöyle ki inşası, düşüncesi veya düşünceleri, dinsel törenleri ve varllğıyla Kilise'yi Cennetten gelen İsa tarafından miras bırakılmış bir şey olarak yorumlamak doğru değildir. Bilakis Hiristiyanlık, içinde Yunanistan'dan, Roma'dan, Filistin'den, İsa'nın havarilerinden, Paul'un adamlarından, yontma taş çağından (ki buna ait husus, cenaze gömme adetidir), Zerdüştlük'ten, Ortaçağ Avrupası'ndan, ... gelen kimseler barındıran, insanlığın manevi hayatına ait çok önemli bir harekettir.

W. Cantwell Smith'e göre hem İslam hem de Hiristiyan gelenekleri üzerine her sabah doğan güneş, onları belli ölçüde insani olanın üstünü kaplayan, onu güçlendiren, zorlayan veya en azından ona karışan bir aşkınlığa ve ilahi lutfa doğru ilerletmiştir. Hiristiyan ve İslam geleneklerinin her ikisi de dinamik, sürekli değişen, her yeni güne ve yüzylla, yeni coğrafi, sosyal, ekonomik, felsefi ve insani yapılara karşlık veren hareketlerdir. Onların her ikisi de, her saniye kendilerini aşmaktan ziyade daha büyük bir yapıya katılmışlardır. ${ }^{33}$

W. Cantwell Smith'in burada ulaşmaya çalıştığı nokta, İslam ve Hıristiyan geleneklerinin her ikisinin de, şu an için on dört yüzyıldır, önemli ölçüde biri diğeri tarafindan belirlenip oluşturulan daha büyük bir yapıya dahil olduklarıdır. Ona göre, hem Hiristiyanların hem de Müslümanların tarihi, büyük ölçüde insanllğın tarihi süreçte dünya genelinde sahip olduğu dindarllğa ait tarihin birer görünen ön yüzüdür. Bunun ötesinde onlar, en azından İslam-Hıristiyan tarihi olarak adlandırılabilecek bir gelişim bütünü olarak görülmek zorundadır.

33 Smith, W. Cantwell, a.g.e, s. 253-254. 
$\mathrm{Bu}$ bağlamda örneğin Haçlı seferleri, Batı tarihinde uzun süre Hiristiyanlığa ait bir olgu olarak görülmüştür. Onlar, daha yeni yeni çarpıcı bir şekilde İslam tarihinin kendi içindeki olaylar olarak çalışılmaya başlanmıştır. ${ }^{34}$ W. Cantwell Smith'e göre, İslam-Hıristiyan bütününe ait ortak tarih içinde ortaya çıkan ve İspanyol tecrübesinde zirve yapan birer kriz olarak görülmediği müddetçe, özellikle dini tarihte gerçekleşmiş birer olgu olarak Haçlı seferlerine dair yeterli bir kavrayışa sahip olunması söz konusu değildir.

W. Cantwell Smith, bu bağlamda ileri sürdüğü tezi desteklemek için bazı örnekler verir. Bunlardan biri, Hıristiyan Skolastisizmi (Ortaçağ Düşüncesi)'dir. Ona göre Batılı düşünce tarihçileri, zaman içinde onun üzerindeki hem Müslümanlara, hem de Yahudiler'e ait Arap Ortaçağ Düşüncesi’ne dair etkiyi fark etme noktasına gelmişlerdir. Bu konuda bir üçüncü aşama daha katedilmiştir ki, o da İslam, Yahudi ve Hıristiyan düşüncelerinin, hep birlikte tarihi olarak Skolastik düşünce olarak adlandırılan bir Akdeniz düşünce hareketine dahil olduklarının görülmesidir. ${ }^{35}$

W. Cantwell Smith'e göre gerçekte hem İslam, hem de Hiristiyanlık tarihinin, bütün kendine has yönleriyle birlikte insanoğluna ait dünyanın en büyük manevi hareketlerinden biri olan Teizm'in görünen ön yüzleri olarak görüleceği bir zaman dilimi gelmektedir. Bu aşamada Hiristiyanlar ile Müslümanlar arasında belli noktalarda göze çarpan farklilıkları, kısmen Hıristiyan ve Müslüman toplumların kendi içlerindeki karşılaştırılabilir farklılıklarla eşleştirmek mümkündür. Dolayısıyla karşılaştırmalı dinler tarihi, bizlere farklı gelenekler arasındakiler kadar yüzyıllar boyunca aynı gelenek içinde ortaya çıkan farklılıkları görmek için de gerekli olan bir perspektif/bakış açısı sunmaktadır.

W. Cantwell Smith, bu noktada kendisine, bütün bu anlatılanların çok güzel olmakla birlikte tarihi süreçte ne Hiristiyanların Müslüman, ne de Müslümanların Hıristiyan oldukları şeklinde bir itirazın gelebileceğini itiraf eder. $\mathrm{Bu}$ noktada teoloji ile dinler tarihinin birbirinden farklı iki alan olduğunu vurgulayan W. Cantwell Smith, sanılanın aksine bu itirazın o kadar da geçerli olmadığını söyler. Şöyle ki İsa figürü, İslam'da sskalanıp kaybedilmemiştir. Elbette orada, İsa'ya Hıristiyan Kilisesinde olduğundan daha farklı bir şekilde yaklaşılmıştır. Fakat bu figürün sunuluşu ve ona yaklaşım tarzı, bizzat Batılı Hıristiyan çevrelerde de gruptan gruba ve asırdan asıra farklılik arzetmiştir. ${ }^{36}$

\footnotetext{
34 Müellif, burada İslam'1, muhtemelen kelime anlamından yola çıkarak bütün İbrahimi geleneği ifade etmek üzere kullanmaktadır. Nitekim o, daha sonra ortaya konacağı üzere Hıristiyanlar’’ da "kendilerini Tanrı'ya adayan kimseler" olarak Müslüman kabul etmektedir.

35 Smith, W. Cantwell, a.g.e, s. 255.

36 Smith, W. Cantwell, a.g.e, s. 257-259.
} 
Bu aşamada daha önce Doğu, Batı ve Merkez şeklinde yaptığı üçlü tasnife geri dönen W. Cantwell Smith, Filistin'den doğan Merkezi hareketin Yahudiler olarak devam ettiğini söyler. Diğer ikisi olan Doğu ve Batı ise, Hiristiyan hareketler olarak ortaya çıkmışır. Belli bir dönem için bu ikisi de, kendi içinde tarihi ve coğrafi olarak (soldan sağa doğru) üç bölgeye bölünmüştür; Latince konuşan, Yunanca konuşan ve Semitik konuşan. Bunlardan önce oluşan ilk ikisi, bize günümüzdeki Kilise'yi kazandıran unsurlardır.

$\mathrm{Bu}$ hareketlerin her birinin, kendi yolunda dinamik, yaratıc1 ve yapıcı bir şekilde geliştiğini söyleyen W. Cantwell Smith, Batı'nın kendi metafiziksel Hıristiyanlığını oluştururken Semitik dünyanın bunları ve esas olarak onların eklemlendiği Yunan kategorilerini asla tam olarak anlamadığını, bu nedenle kısa süre sonra Hz. İsa'yı unutmayan fakat Semitik dillerde düşünen dini hareketlerin çoğunun, bizim İslam olarak adlandırdı̆̆ımız başka bir metafizik çatıyı benimsediğini ifade eder. Bu noktada Batı Kilisesi, onları Hıristiyan olmayı terk etmekle suçlarken, nihai gerçeğin bu yeni yorumu ve formülasyonunu benimseyen kimseler, onlara karşı kendilerini, aslında Hıristiyan İsa'yı şimdi çok daha iyi anladıkları ve yücelttikleri şeklinde savunmuşlardır.

W. Cantwell Smith, Batı'lı Hıristiyanlar'ın gerçekte bu bakış açısını dikkate alıp onun üzerinde durma ve düşünme gereğini hiç hissetmediklerini; çünkü onların, Batı Kilisesi'nin Hıristiyanllğa ait formülasyonların nihai gerçekler olduğunu varsaydıklarını, fakat bugün için kendilerinin onların tarihi birer olgu olduklarını bildiklerini söyler. Ona göre bu formülasyonlar, onların gördükleri, hissettikleri ve içsel olarak kavradıkları şeyleri, belli kavramlar ve ifadeler halinde formüle etme teşebbüslerinden ibarettir. ${ }^{37}$

W. Cantwell Smith, bu noktada bir kimsenin cesur bir tavırla şu soruyu sorabileceğini söyler: "Şayet Isa, bugün kalksp yeryürzüne tekrar dönse, o mubtemelen ş̈̈le mi diyecelktir; "Müslümanlar, beni Hiristiyanlar'dan daba iyi anladı!"

W. Cantwell Smith, bu soruyu öncelikle bir dinler tarihçisi gözüyle cevaplamaya çalışır. Buna göre insan olan İsa, bazı kimselerin düşüncesi ve ruhu üzerinde çok büyük etki bırakmıştır. Öyle ki, onun hafızası, ilhamı, örnekliği, öğretisi ve etkisi etrafinda güçlü ve devamlı bir hareket kristalize olmuştur. Batı Kilisesi'nde İsa, aşkınlığın; dünyaya ait, kişiye ait, (insandaki Tanrı ve Tanrı'daki insana ait), insanllğın mükemmellikle olan ilişkisine dair aşkınlığın bir sembolü haline gelmiştir. Böyle bir sembol haline gelmesi nedeniyle aslında kişi olarak İsa, çok da iyi bilinmemektedir; zira onun hakkındaki bilgiler, daha ziyade onun hakkındaki birkaç hikaye, efsane, bilgi kırıntısı -ve nesilden nesile geçen canlı

37 Smith, W. Cantwell, a.g.e, s. 259-260. 
bir enerjiden ibarettir. $\mathrm{O}$, aynı zamanda erkek ve kadınların aşkınlığa yönelik açılı̆ı̆ının devamı olmuştur.

Hz. İsa'nın Doğu dünyasındaki hikayesi, bazı yönlerden buna benzerken bazı yönlerden ondan değişiktir. Orada da onun hafızası hatırasında yaşanır, öğretisine sayg1 duyulur ve örnekliği idealize edilir. Bununla birlikte orada, farklı bir dini ve metafizik yapı inșa edilmiștir. Onlar, kendi vizyonlanını, deneyimlerini ve farkındalıklarını daha değişik yollarla formüle etmişlerdir. Şöyle ki onların oluşturduğu yapiya Yunan'dan ve Roma'dan daha az unsur girerken, tahmin edileceği üzere Filistin veya Semitik mirastan daha fazla husus gelmiştir. Burada, metafiziksel ve humanist unsurlar daha az görülürken, Tanrı düşüncesi ve ahlaki emirler çok daha fazla vurgulanmıştır. Birkaç yüzyıl sonra ise, orada Arabistan'dan çıan Mubammed isimli bir Arap vaiz tarafindan oluşturulan kavramsal bir çatı benimsenmiştir. ${ }^{38}$ Bazılarının iddia ettiği gibi o kadar da yeni olmayan bu yeni çatı altında milyonlarca insan, kendilerinin $\mathrm{Hz}$. İsa'nın yolunda olduklarını; ama onu Tanrı'ya bağllık içinde takip ettiklerini iddia etmişler ve hala daha takip etmeye de devam etmektedirler.

W. Cantwell Smith, bu hareketle birlikte toplumun Doğu ve Batı arasında tehlikeli bir şekilde ikiye bölündügünü kabul eder. Ona göre Kuzey Avrupa'daki Otuz Yıl Savaşları ile günümüzde Kuzey Irlanda'da ortaya çıkan halihazır olaylar, her biri Hz. İsa'nın takipçileri olduğunu iddia etmelerine ve tarihçiler her ikisini de Hiristiyan olarak adlandırmalarına rağmen Katolikler ile Protestanların zorunlu olarak ille de tek bir toplum oluşturmadığını göstermektedir. Dolayısıyla bir inanç toplumunu, doktrinsel formülasyonlara ve paylaşılan diğer sembollere ait farklılıkların ötesinde tanıyıp kabul etmek gerekir. ${ }^{39}$

Bu noktada W. Cantwell Smith, Batılı tarihçilerin İslam'ı yedinci yüzyılda Arabistan'da başlayan bir din olarak gördüklerini söyler. Bununla birlikte Müslümanlar, İslam'ın şayet daha önce değilse yaratılış gününde başladığını kabul ederler; zira onlara göre Hz. İbrahim de bir müslümandır, Hz. İsa da. ${ }^{40}$ Ona göre bu kabulleri anlamamak (hatta kabul etmemek), İslam'ı anlamamak olduğu gibi, Hz. İbrahim'i ve Hz. İsa'y1 da anlamamak; veya en azından Arapça'yı bilmemektir.

\footnotetext{
38 Müellif, burada Hz. Peygamber'i “Arab preacher/Arap vaiz” olarak tanımlamaktadır. Zira ona göre İslam'da Kur'an'ın konumu Hıristiyanlıkta Hz. İsa'ya, Hz. Peygamber'in konumu ise St. Paul'e denk düşmektedir. (Bkz. Smith, W. Cantwell, a.g.e, s. 238-239) Bu, İslam dini açısından kabul edilemez bir kıyaslamadır: "Allah'ın peygamberlerinden hiçbiri arasında ayırım yapmayız." (Bakara 2/285)

39 Smith, W. Cantwell, a.g.e, s. 261-262.

40 Maide 5/112.
} 
W. Cantwell Smith, geleneksel Hıristiyanlar gibi geleneksel Müslüman teologların da, muhtemelen ötekileri dışlama eğiliminde olduklarını, fakat modern liberal bir Müslüman düşünürün, sufilerin klasik olarak yaptıkları gibi, kuşkusuz kendilerini imanla Tanrı'ya adamış olmaları itibarıly Hıristiyanların da İslam teriminin hakiki anlamında müslüman olmuş olduklarını kabul edeceğini söyler. ${ }^{41}$

Nihai aşamada W. Cantwell Smith, bu gibi hususlarla yakından ilgili bir ilim adamı olarak konuyla ilgili kendi görüşünü açıkça ortaya koymanın faydalı olacağını ifade eder. Ona göre Hıristiyanlar, sahip oldukları akılları ve hislerinin yükselebildiği en yüksek 1şık altında tarihleri boyunca en yüksek anlamda müslüman olmuşlardır. Nitekim onlar, İslam kelimesinin literal terim anlamında (teslim olma) kendilerini Tanrı'nın iradesine ve gerçeğine adamışlardır ki onlar, bu durumun gayet iyi bir şekilde farkındadırlar. Aynı şekilde Müslümanlar da sahip oldukları akılları ve hislerinin yükselebildiği en yüksek ışık altında en üst düzeyde tarihleri boyunca Hiristiyan olmuşlardır. Nitekim onlar, Hiristiyan kelimesinin literal terim anlamında kendileri Hz. İsa'nın takipçileri ve sevip sayanları olmuşlardır ki, onlar da bu durumun gayet iyi bir şekilde farkındadırlar. Şayet buna, Müslümanların kelimenin tam anlamıla Hıristiyan, Hıristiyanların da kelimenin tam anlamılla Müslüman olmadıkları şeklinde karşılık verilirse, bu takdirde buna hemen şu şekilde cevap verilebilir ki, ona kalırsa çok az Hıristiyan gerçek anlamda Hıristiyan, aynı şekilde çok az Müslüman da gerçek anlamda Müslüman olmuştur. ${ }^{42}$

W. Cantwell Smith, böyle bir süreçte kendilerinin haklı olarak kısmen de olsa her iki kesimi birbirinden ve diğerlerinden ayırt etmeyi ummak zorunda olduklarını kabul eder. Bununla birlikte o, kendilerinin diğerlerinin çabalarına, onların seçimlerine ve tarihi gelişim süreçlerine sayg1 duyabileceğini ve duymaları gerektiğini; onlardan da kendilerine sayg1 duymalarını beklediğini ifade eder. Zira ona göre modern dünyada hepimiz, bunları aydınlatabilmek için ortaklaşa bir gerçeklik ve dürüstlük arayışı içinde, bütün ilahi inisiyatiflere karşılık verme çabası içinde olmalıyız.

Netice itibarıly W. Cantwell Smith'e göre, modern bir tarih yazıcıllğı, hatta modern bir teoloji, şayet bilimsellik arzedecekse, Müslüman-Hıristiyan ilişkileri meselesinde bu iki kesime farklı, fakat ayrı olmayan tek bir yapının kavramları içinde yaklaşmak zorundadır; zira onlar, dinamik bir bütünün farklı unsurları olarak anlaşılmalıdır. Maalesef Müslüman-Hıristiyan ilişkilerine ait bir tarih, henüz ne yazılmış, ne de yazılması düşünülmüş bir şeydir. Ona göre bu tarihe dair farklı, fakat doğru bir kavrayış ve formülasyon, ancak kendisini

41 Smith, W. Cantwell, a.g.e, s. 262.

42 Smith, W. Cantwell, a.g.e, s. 262-263. 
bütüncül bir kompleks içinde gören ve bunu bu şekilde sunabilen bir kimsenin çalışması olacaktır. Çünkü bu tarihin her bir üyesi, gerçekte bu bütüncül yap1 içinde onunla birlikte varolmuş; onun tarihi de, bu aşkın gerçek sebebiyle söz konusu bütüncül yap1 içinde gerçekleşen şey olmuştur. Ve tıpk1 KatolikProtestan ilişkilerinde olduğu gibi, İslam-Hıristiyan karşılaşmasına ait tarih, biz onu Tanrı'yla ilişkisi ondört yüzyıldır bu iki farklı yapı içinde gelişen insanların birbirine geçmiş kaderi olarak görmeyi öğrendiğimizde yeni bir aşamaya gelmiş olacaktır. ${ }^{43}$

\section{B. TEVRAT VE İNCİL'IN GÜVENİRLİĞİ - KUR'AN'IN İLAHİLIĞİ:}

Süleyman Ateş ile W. Cantwell Smith'in çalı̧smalarında üzerinde durdukları bir diğer önemli husus kutsal kitapların durumu, diğer bir deyişle bu kitapların onları benimseyenleri kurtuluşa erdirmek için yeterli olup olmadığıdır. İlginç bir şekilde bu önemli konuda S. Ateş Tevrat ve İncil'in güvenirliği, W.C. Smith ise Kur'an'ın ilahiliği üzerinde durmakta ve her ikisi de, onlar hakkında geleneksel yaklaşımdan farklı şeyler söylemektedirler.

S. Ateş, ilahi dinlere ait her üç kutsal kitabın da öz itibarıly aynı olup, insanlığa din olarak İslam'1; yani aynı inanç, ibadet ve ahlak esaslarını bildirdiklerini söyler. Ona göre bu noktada onlardan sonuncusu olan Kur'an'ın temel özelliği, sonradan oluşan geleneksel İslam anlayışında iddia edildiği üzere onları neshedip hükümsüz bırakması değil, bilakis tasdik edip onaylamasıdır: “Biz, sana bu Kitab'1, kendinden önceki Kitab’1 doğrulayıc1 olarak indirdik."

S. Ateş'e göre, Kur'an'ın burada doğrulayıp onayladığı Kitap, aslı bozulmuş, ortadan kalkmış, mevcut olmayan bir kitap değil, tam tersine Kur'an indiği sırada Kitap Ehlinin ellerinde bulunan Kitap'tır; çünkü bu husus, şu ayet-i kerimede çok açı bir şekilde ifade edilmektedir: "Sizin yanınızda bulunan (Kitab)1 doğrulayıcı olarak indirdiğimiz (Kur'an)a inanın, onu ilk inkar eden siz olmayin." 45

S. Ateş, Hz. Yakub'un kendisine haram kıldığı şeyler dışında bütün yiyeceklerin İsrailoğullarına helal olduğunu; Kur'an'da, bunun Tevrat'ta böyle yazıldığı; aksini iddia edenlerin Tevrat'ı getirip okumalarının buyrulduğunu ifade eder: "Tevrat indirilmeden önce, İsrail'in kendisine haram kıldığ1 şeyler dışında, İsrailoğullarına bütün yiyecekler helal idi. De ki; 'Doğru iseniz. Tevrat' getirip okuyun?'46

\footnotetext{
43 Smith, W. Cantwell, a.g.e, s. 263-264.

44 Maide 5/48.

45 Bakara 2/41. (Bkz. Ateş, Süleyman, Çağdaş Tefsir, I, 151-156)

46 Al-i İmran 3/93.
} 
S. Ateş'e göre, şayet Kur'an'da zikredilen Tevrat, Yahudiler'in elinde olan Tevrat'ın kendisi olmasayd, o zaman Kur'an'ın Yahudiler'den Tevrat'ı getirip okumalarını istemesi anlamsız ve abes olurdu. Demek ki, Tevrat'ın aslı onların elinde mevcuttur. Nitekim Hz. Yakub'un kendisine haram kıldığ şeyler, Tevrat'ın 32. babında şu şekilde anlatılmaktadır: "Yakub, gece kalkıp iki karrsı, iki cariyesi ile onbir çocuğunu ald ve Yabbok geçidini geçti... Yakub yalnı zaşına kald ve seber sökü̈nceye kadar bir adam onunla gürești. Onu yenemediğini görünce uyluğunun bașına dokundu ve Yakub'un uyluk. bașt incindi... Penuel'i gectiği zaman güneş üzerine doğru ve uyluğu üzerine akssriyordu. Bunun için bugüne kadar İsrailoğullar, uyluk başı üzerindeki kalsa adalesini yemezler; çünkü Yakub'un uyluk başına, kalça adalesine dokundu." 47

Bununla birlikte S. Ateş, daha sonra Yahudiler'in, Tevrat ayetlerini kendi arzuları doğrultusunda yorumlayarak bir takım tefsir ve ahkam kitapları yazdıklarını ve bunlardan en meşhurunun Talmud olduğunu söyler. Ona göre Yahudi din adamları, yazdıkları şerhler ile Kitab'ın aslında bulunmayan ayrıntılara dair ictihadi hükümlerini Allah'n buyrukları olarak görmüş ve halka bunların da Tanr1 buyruğu olduğunu söylemişlerdir. Oysa bunlar, onların kendilerinin ve hakim tabakanın arzu ve çıarlarından başka bir şey içermemektedir. İște Kur'an'da eleştirilen husus, budur: 'V ay haline o kimselerin ki, elleriyle Kitab' yažp, az bir paraya satmak için; 'Bu, Allah katmdander,' derler. Ellerinin yazdğgndan ötürü vay haline onlarn! Kazandıklarmdan ötürü vay haline onlarn?' 48

S. Ateş, İslami gelenekte yer alan Kur'an'ın önceki kitapları neshedip hükümsüz biraktı̆̆1 görüşünü kabul etmez. Ona göre böyle bir şeyin olabilmesi için öncelikle onlarda yer alan hükümlerin yanlış ve uygulanamaz olması gerekir. Halbuki Kur'an, Tevrat ve İncil'i tam tersine birer nur, rahmet ve hidayet kaynağ1 olarak görmektedir: "Tevrat'? biz indirdik. Onda bidayet ve nur vardir.", ${ }^{49}$ "İsa'ya içinde bidayet ve nur bulunan, önündeki Tevrat'? doğrulayan ve korunanlar için yol gösterici ve öğü olan Incil'i verdik." 50

S. Ateş, bu doğrultuda Tevrat'in hükümlerini uygulayan Yahudi din adamlarının övülüp, bunları uygulamayanların kafir ilan edildiğini söyler: "Bi\%, içinde doğruy a rehberlike ve nur olduğu balde Tevrat'ı indirdik. Kendilerini (Allab'a) vermis peygamberler onunla Yabudilere bükemederlerdi. Allab'm Kitab'm korumalar kendilerinden istendiği için Rablerine teslim olmus zâbidler ve bilginler de (onunla bükmederlerdi). Hepsi ona (bak olduğuna) şabitlerdi. Şu balde (Ey yabudiler ve hakimler!) İnsanlardan korkmayzn, benden korkun. Ayetlerimi az bir bedel karşzllğgnda satmayin.

47 Eski Ahit, Tekvin 32/22-31.

48 Bakara 2/79. (Ateş, S., a.g.m., s. 9-10)

49 Maide 5/44. (Bkz. Ateş, Süleyman, Çăgdaş Tefsir, II, 533-537)

50 Maide 5/46. 
Kim Allah'ın indirdiği (bükü̈mler) ile bükmetmezse işte onlar kâfirlerin ta kendileridir. Tevrat'ta onlara şölle yazdlk: Cana can, göze göz, ..." 51

S. Ateş'e göre, bu ayetlerin geçmiş dönemde yaşayan Kitap Ehline ait hususlar olduğu iddiası doğru değildir. Çünkü Kur'an'da doğrudan Hz. Peygamber'e hitap edilmek suretiyle Yahudiler'den bizzat kendi kitaplarıyla amel etmeleri istenmektedir: "İiinde Allah'm bükmü bulunan Tevrat yanlarnnda dururken seni nasıl hakem yapyorlar da, sonra (senin verdiğin büküm ișlerine gelmeyince gerisin geri) dönïyorlar? Onlar inamuc değiller." 52

S. Ateş'e göre, aynı şekilde İncil ehlinden de, ellerinde bulunan Kitab'a göre hüküm vermeleri istenmektedir: 'Incil sahipleri, Allah'in onda indirdig̈ryle bükmetsinler. Allab'in indirdiğiyle bükmetmeyenler yoldan çımıslardır. '53

S. Ateş, geleneksel kabulün aksine Kur'an'a göre Kitap Ehlinin yoldan çıkma nedeninin onların ellerindeki aslı olmayan Tevrat ve İncil'e uymaları değil, bilakis onlara göre amel etmemeleri olduğunu söyler: "Ëğer onlar, Tevrat', Incil'i ve Rablerinden kendilerine indirileni uygulasalard, mubakekak ki üstlerinde (ki ağaçlarn meyvelerinde)n ve ayaklarmmn altnndaki ürünlerden yerlerdi. İ lerinde doğru yolda giden ılimlı bir topluluk var ama, çoğu ne kötü işler yapıyorlar?... De ki: 'Ey Kitab ebli, siz, Tevrat'c ile Incil'i ve Rabbinizden size indirileni uygulamadlkşa bir esas üzerinde değilsini:!'54

S. Ateş, son aşamada şu soruyu sorar: Şimdi eğer Kur'an indiği sırada Tevrat ve İncil muharref, aslı yok ve Kur'an onları tamamen neshetmiş, ortadan kaldırmış ise, nasıl Yahudiler'e Tevrat'in hükmünü uygulamaları, Hıristiyanlar'a İncil'in hükmünü uygulamaları ve genel olarak Kitap Ehline, Tevrat ve İncil'in hükümlerini uygulamaları emredilir? Olmayan, yahut neshedilen şey nasıl uygulanır? Tam tersine ona göre Kur'an, Kitap Ehline, kitaplarını doğru dürüst uygulamalarını vurguladıktan sonra bütün ilahi dinlerin özde birliğini ve bunları gereğince uygulayanların hepsinin mutluluğa ereceğini belirtmek üzere şöyle buyurmuştur: 'İnananlar, Yabudiler, Sabiiler ve Hiristiyanlar(dan) Allab'a ve abiret gününe inanan ve iyi işler yapanlara korku yoktur ve onlar ü̈ülmeyeceklerdir. '55

S. Ateş, bu konuda Hz. Peygamber'in sünnetinden de deliller getirir. Buna göre Yahudi alimlerinden Abdullah b. Selam (ö.43/663) Müslüman olmuştur. Bir gün Hz. Peygamber, onu yorgun görüp sebebini sorar. Abdullah, gece boyunca uyumadığını; hem Tevrat'1, hem de Kur'an'ı okuduğunu söyler. Bunun üzerine Hz. Peygamber, öyle iki kitabı aynı gecede okumamasını, bir

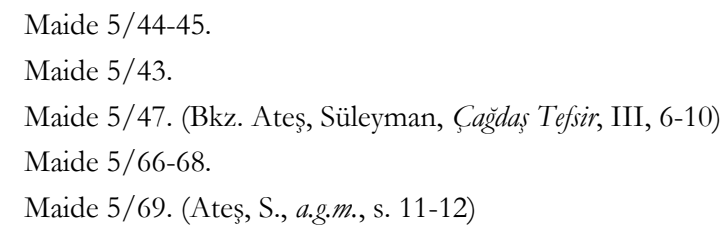


gece Kuran'1, diğer gece de Tevrat'ı okumasını emreder. Benzer şekilde Hendek savaşı sonrasında Hz. Peygamber, Müslümanlarla anlaşmalarını bozup müşrik ordusuyla Müslümanlara karşı işbirliği yapan Yahudi Kurayza Oğullarına Tevrat'ın belirlediği cezayı vermiş, yani Yahudilere kendi kitaplarıyla hükmetmiştir. ${ }^{56}$

S. Ateş, aradaki muhteva birliğinden dolayı İmam Azam Ebu Hanife'nin de namazında Kur'an ayeti yerine Tevrat'tan ayet okuyan ve okuduğu ayet Kur'an'a uygun düşen kimsenin namazının sahih olacağına hükmettiğini söyler. ${ }^{57}$

W. Cantwell Smith, bu bağlamda Kur’an-1 Kerim'in ilahiliği üzerinde durur. O, "Kur'an Tanrr'nın sözü müdür?" şeklinde bir soruyla dile getirdiği bu konuda, geleneksel anlayışlardan farklı olarak her iki kesim tarafindan üzerinde uzlaşılabilecek ortak bir cevap arayışı içindedir.

W. Cantwell Smith, geçmişte normal olarak bu soruya "evet" veya "hayır" şeklinde iki cevap verildiğini söyler. Bazı kimseler onlardan birini, bazıları da diğerini seçmişler; fakat hangi cevap olursa olsun o, kendinden emin bir kesinlik içinde ve güçlü bir şekilde verilmiştir. Bu bağlamda insanların büyük kesimi, yaklaşık ondört asırdır bu cevaplar doğrultusunda keskin bir şekilde iki gruba bölünmüş; Kur'an'ın Tanrı'nın sözü olduğunu benimseyenlerle olmadığını söyleyenler arasındaki sınırlar çok net, ayrılıklar da oldukça derin olmuştur.

W. Cantwell Smith, meseleye Batılı oryantalizm üzerinden çözüm üretmeye çalışır. Ona göre Batılı oryantalistler Kur'an'a yedinci asra ait edebi bir eser gözüyle bakmış ve bu bağlamda onun hakkında pek çok gerçeği açığa çıkarıp bunları güzel bir şekilde açıklamışlardır. Bununla birlikte onlar, Kur'an’ı müslüman toplumun dini yaşamına sadece yedinci asırda değil, bilakis sekizinci, onikinci ve yirminci yüzylllarda da hayat veren, iman sahibi kimselerin sürekli olarak kendisinden beslendiği, daima çağdaş ve ebedi kalan bir kitap olarak göremediler. $\mathrm{Bu}$ nedenle de onun asırlar boyunca inançlı Müslümanlar için gerçekleştirmiş olduğu bu şeyi başarma noktasına nasıl geldiği sorusuna cevap veremediler. Dolayısıyla artık şunun farkına varılmıştır ki, geleneksel Batı cevabı, bu olgunun yalnızca bir kısmını açıklamaktadır; o, gidebildiği yere kadar

56 "Allah, ebl-i kitaptan, onlara (müsrik ordularna) yardm edenleri kalelerinden indirdi ve kalplerine korku düşürdü; bir kıısmm öldürüyor, bir kısmm da esir alyyordunuz. Allah, onlarn yerlerine, yurtlarna, mallarna ve ayak basmadiğmnz, topraklara siz̨i mirassc yaptı. Allab'ın her seye gücü yeter." (Ahzab 33/26-27) (Bkz. et-Taberi, Camiu'l-Beyan, XXI, 150-155)

57 es-Serahsi, Ebu Bekr, el-Mebsut, Beyrut tz, I, 234. (Ateş, S., a.g.m., s. 16, 22) 
doğrudur, fakat gittikçe artan bir şekilde açığa çıkmıştır ki artık o, bugün için gereğince yeterli gelmemektedir.

W. Cantwell Smith, buna bağlı olarak artık gayr-1 Müslim Batı'nın, "hayır" cevabını yumuşatmaya, hatta geri çekmeye başladığını iddia eder. O, buna Harvard'da Arapça Profösörü olan Batılı İslam yazarlarının düayeni Sir Hamilton Gibb'in, yeni bir makalesinde açıkça yer verdiği şu ifadeyi örnek gösterir:

"Şahsen ben, Muhammed'in kişisel tecrübesinin ifadesi anlamında "Revelation/Vahiy" kavramını (Arapça'daki "tenzil/vahiy indirme" veya "vahiy/iç iletişim”) tereddütsüz olarak kabul ediyorum. Dolayısıyla diğer monoteist dinler gibi İslam da, "vahy"e ait artık savunulması imkansız olan Ortaçağa ait kavramların ötesinde yeniden yorumlanma zaruretiyle karşı karşıyadır." 58

W. Cantwell Smith, benzer şekilde Müslümanlara karşı Protestan misyonerliğinin teorisyen lideri olan Kenneth Cragg gibi Hiristiyan bir teoloğun da, artık Kur'an'a onu teolojik olarak reddederek yaklaşmadığını savunur. ${ }^{59}$

Ona göre daha sonraki ilim adamları nesli, geleneksel Müslüman cevabını kabul etmemekle birlikte geleneksel gayr-1 Müslim cevabının ötesine geçecektir. Onların bu soruya ne cevap vereceği, henüz kendileri için de belli değildir. İslam'ın gayr-1 Müslim gözlemcileri, şu an için ilk defa burada tartsşılan soruyu açıkça dile getirmekle meşguller. Muhtemelen bir araştırmanın orta yerinde, bu soruya ne basitçe "evet", ne de basitçe "hayır" şeklinde olan, bilakis bu ikisinden çok daha hassas, daha kompleks ve daha iyi işlenmiş yeni bir cevap önerilecektir.

W. Cantwell Smith'e göre benzer gelişmeler, Müslüman dünyasında; geleneksel olarak doğrudan "evet" cevab1 veren kesimde de görülmektedir. Şöyle ki bu cevap, Batı'lı çalışmaların Kur'an hakkında Müslümanlar için de kullanılabilir kıldığı yeni tarihi verileri ele almaya yeterli gelmemektedir. Nitekim şüpheci tarihsel kritiğin dışarıdan ithal ettiği bilgi ve yeniden inşalar, geleneksel "evet" cevabını kendi geleneksel formu içinde yetersiz kılmaktadır. Bugüne kadar Müslümanlar, gayr-1 Müslim çalışmaları Bat1 emperyalizminin bir parçası olarak görüp reddetmiştir. Fakat gelinen noktada bu hususlar, sadece Batılllar tarafindan değil, aynı zamanda Hindistan'da Hindular, Japonya'da Budistler,

58 Gibb, Hamilton A. R., "Pre-Islamic Monotheism in Arabia", Harvard Theological Review, 55, 1962, s. 269.

59 Bkz. Cragg, Kenneth, The Call of The Minaret, New York 1956; Sandals at The Mosque; LondraNew York 1958.. 
hatta belli ölçüde bizzat Müslümanların yeni nesilleri tarafindan da dikkate alınmaktadır. Çünkü izolasyona dayalı bakış açısı, artık kaybolmaktadır. ${ }^{60}$

Netice itibarıyla W. Cantwell Smith, Kur'an'ın beşeri bir ürün olduğuna dair önyargıya anlam kazandıran tarihi gerçeklerin, artık Müslümanlar tarafindan inkar edilemeyeceği gibi, aynı şekilde Kur'an'ın ilahi bir söz, Tanrı'nın inanan kimseleri kurtuluşa erdireceği gücü olduğu önyargısına anlam kazandıran dini gerçeklerin de dışarıdan bakanlar tarafından inkar edilemeyeceğini söyler. Zira bu aşamada her iki kesim de yenilikçi bir potansiyelle birbirlerinin kitaplarını ele alıp cesaretle incelemeye başlamıştır. Bunun ötesinde günümüzde izolasyonun sona ermeye başladığını gösterecek tarzda içinde hem Batılı hem de Müslüman araştırmacıların birlikte çalıştığ yeni akademik merkezler kurulmaktadır. Dolayısıyla artık Batılı biri tarafindan İslam hakkında yapılan her gönderme bilinçli olarak Müslümanların önünde ortaya konmakta, aynı şekilde İslam hakkında bir Müslüman tarafından yapılan her gönderme de ilgili soruya açık bir şekilde "hayır" cevabı veren kimselerin önünde yapılmaktadır.

W. Cantwell Smith, Pakistan'lı modern ilim adamı Fazlurrahman'dan hareketle Müslüman dünyada üst düzey zekaya ve dürüst kimliğe sahip kimselerin, bir yandan kendi toplumundaki aşkın unsura eşit ölçüde hakkını verirken, aynı zamanda ufku global ve tarihi anlayışı gerçekçi olan kimseler için de anlamlı ve ikna edici olacak cevap arayışlanı içinde olduklarını ifade eder. ${ }^{61}$

W. Cantwell Smith, bu aşamada bilginin bütünlüğüne ve insanlığın birliğine inanan bir kimse olarak şöyle bir hayali olduğunu ifade eder: Bu soruya gayr1 Müslimleri tatmin edecek yegane cevap ile Müslümanları tatmin edecek yegane cevap, önümüzdeki yıllar içinde hemen hemen aynı cevap olacaktır. Bunun, Hıristiyan teolojisi gibi İslam teolojisi için de bir son olacağının farkında olduğunu belirten W. Cantwell Smith, bunun çok radikal bir görüş olmasindan rahatsızlık duymadığını, zira kendisinin 20. ve 21. yüzylllarda insanlığa ait dini tarihin, büyük bir yeni dönüşüm yaşayacağına inandığını söyler.

W. Cantwell Smith, burada Hıristiyanlar ile Müslümanların farklı olmaya son vereceğini kastetmediğini, fakat her ne kadar ahlaki olarak farklı şekilde cevap vermeyi seçseler de, ilmi/akli olarak onların anlayışlarının bir noktada birleşmesi gerektiğini belirtir. Ona göre evrene yönelik reaksiyonlar ve varoluşsal dini cevaplar, muhtemelen şahsi veya gruplara ait olmaya devam edebilir. Bununla birlikte onu evrensel k1lmaya yönelik teori, biz entellektüellerin işidir.

60 Smith, W. Cantwell, a.g.e, s. 293-297.

61 Bkz. Fazlurrahman, Probhecy in Islam: Philosophy and Orthodoxy, Londra-New York, 1958. 
Ona göre, şu anda olanın tersine Hiristiyan teologlar gelecekte profesyonel anlamda İslam teolojisine ait merkezi konular üzerine çalışacaklar, bu onun tezini sadece doğru değil, aynı zamanda canlı hale getirecek ve insanlığın dini gelişimindeki yeni çağ buradan ortaya çıkacaktır. Şu aşamada söylenebilecek yegane şey şudur ki; maalesef bizler, Tanr'nın geçmişte insanlarla konuşmuş olduğu ve şimdi konuşmaya devam ettiği bütün yolları tam olarak bilmiyoruz. ${ }^{62}$

\section{EHLİ KİTAB (HRİSTIYYANLAR) İLE MÜSLÜMANLAR ARASINDAKI İMAN BİRLİĞİ, İNANÇ (UYGULAMA/AMEL) AYRILIĞI: ${ }^{63}$}

Süleyman Ateş, konuya Kur'an'a göre Allah'ın, yalnız belli bir zümrenin Rabbi değil, bütün alemlerin Rabbi olduğunu ifade ederek başlar: "Övgü, alemlerin Rabbine mabsustur." 64

O, Allah'ın rahmetinin sadece belli bir zümreye özgü olmayıp, bilakis bütün yaratılmışlara şamil olduğunu söyler: "Rabbiniz, kendisine rahmeti yažmıştır (acmayı kendisine prensip edinmisstir.", ${ }^{65}$ "Rahmetim, her şeyi kaplamıştır.' 66

Buna uygun olarak her peygamber, insanllğa bu sonsuz ilahi rahmeti sunmaya çalış̧ış, Allah'a şirksiz, ahirete şeksiz inanan ve salih amel yapan her ilahi din mensubunu cennetle müjdelemiştir: "Ş̈̈phesiz. (H₹: Mubammed'e) iman edenler, Yabudiler, Hiristiyanlar ve Sabiiler, bunlardan her kim, Allab'a ve abiret gününe inanir, iyi is yaparsa elbette onlara, Rableri katında mükafat varder; onlara korku yoktur ve onlar ü̈zülmeyeceklerdir.'”7

Bununla birlikte $\mathrm{S}$. Ateş'e göre insanların bencilliği, ilahi mesajın geniş ufkunu daraltmış, her din mensubu, sadece kendilerinin cennete girebileceğini iddia etmiştir. Şöyle ki, Yahudiler cenneti yalnız kendilerine tahsis ederken, Hıristiyanlar da kendilerinden başkasına cennet vizesi vermemişler, maalesef daha sonra Müslümanlar da aynı hataya düşmüşlerdir: 'Dediler: 'Yahudi, ya da Heristiyan olandan başkası cennete girmeyecek.' O, onlarn kuruntularddr. 'Doğru iseniz. (bu konuda) delilinizi getirin,' de.'08

62 Smith, W. Cantwell, a.g.e, s. 297-300.

$63 \mathrm{Bu}$ başlıktaki açık ifade esasen W. Cantwell Smith'e aittir. O, burada "belief/inanç" kavramıyla kitabi din mensuplarının tarihi süreç içinde geliştirdiği teolojiyi ve uygulama esaslarını, yani geleneksel din anlayışlarını kastetmektedir. S. Ateş ise, bunu İslam'daki imanamel ayrimiyla ifade eder.

64 Fatiha $1 / 2$.

65 En'am 6/12.

66 A'raf 7/156.

67 Bakara 2/62; Maide 5/69. (Bkz. Ateş, Süleyman, Cağdaş Tefsir, I, 174-176)

68 Bakara 2/111. (Bkz. Bakara 2/112-113, 120, 135; Maide 5/18) 
Halbuki ona göre, cennetin belli bir zümreye mahsus olduğu iddiası bizzat Kur'an tarafindan reddedilmiş, onun iddia ile değil, gerçek iman ve eylem ile olacağ1, Yahudiliği ve Hıristiyanlığ1 getiren peygamberlerin atası İbrahim'in gerçek tevhid dinini getirmiş olduğu, dolayısıyla onun yolunda giden her insanın cennete gireceği söylenmiştir: "Hayır, kim işini güzel yaparak özünü Allab'a teslim ederse, onun mükafat, Rabbinin yanndadr. Onlara korku yoktur ve onlar ürülmeyeceklerdir." 69

S. Ateş, bu noktada Kur'an'da kurtuluş için ortaya konan temel hususların genel ve evrensel olduğunu, dolayısıly kimsenin bunları tekeline alma yetkisi bulunmadığını ifade eder: "(IIs) $)$, ne sižin kuruntularmı\%, ne Kitab eblinin kuruntularna göre olmaz: Kötülïk yapan, onunla cezalandrrlir ve kendisine Allab'tan basska ne dost, ne de yardima bulamaz. Erkek veya kadindan her kim inanarak güzel işler yaparsa, işte ölle kimseler cennete girerler ve zerre kadar haksįlğga uğratılmazlar.”70

S. Ateş, Kur'an'da hiçbir milletin topyekün cehenneme mahkum edilmediğini, zira her milletin içinde iyilerin de kötülerin de bulunduğunu, örneğin geçmişte Yahudiler'in çoğu sapmış olsa da içlerinde 1lımlı, iyi işler yapan, temiz kalpli salih kimseler bulunduğunu söyler: "İ̧̧lerinde aşır gitmeyen, mutedil bir ümmet var, ama çokları sapmaktadrr.",71 "Musa kavmi içinde bakka uyup bak ile adalet yapan bir topluluk da vardir.'’2

S. Ateş, bu durumun geçmiş dönem Ehli Kitab’ı için böyle olduğu gibi Hz. Peygamber dönemi ve sonrası için de geçerli olduğunu söyler. Nitekim Kur'an'da, ilahi mesaja ve peygamberlere karşı olumsuz davranışlar içine giren Yahudiler'in Allah'ın gazabına uğradıkları belirtildikten sonra; hepsinin bir olmadığ1; Kitab ehli içinde Allah'a ve ahirete inanıp, geceleri ibadet eden, hayır işlerine koşan salih kimselerin de bulunduğu ve böyle kimselerin ödüllendirileceği bildirilmektedir: "Ama hepsi bir değildir. Kitap Ehli içinde, gece saatlerinde kalkep Allab'in ayetlerini okuyarak secdeye kapanan bir topluluk da vardr. Onlar, Allab'a ve abirete inamurlar, iyiliği emreder, kötülükten menederler; hayır ișlerine kossarlar. Isste onlar, iyilerdendir. Yapacaklar biçbir iyilik inkar edilemeyecek (yaptıklarmm karşliğg verilecek)tir. Allah, korunanlar bilmektedir."’3

S. Ateş, aynı şekilde son peygamber Hz. Muhammed'e inandığını söyleyen herkesin cennete giremeyeceğini, ancak Allah'a ve ahirete inanıp salih amel yapanların cennete varis olacaklarını ifade eder. Ona göre iman, sadece kuru bir sözden ibaret değildir. Bilakis iman, güzel eylemler biçiminde tezahür

69 Bakara 2/112. (Bkz. Ateş, Süleyman, Çă̆das Tefsir, I, 221-223)

70 Nisa 4/123-124. (Ateş, Süleyman, a.g.m., s. 8-9)

71 Maide 5/66.

72 A'raf 7/159; 169-170, 181.

73 Al-i İmran 3/113-115. (Bkz. Ateş, Süleyman, Çağdaş Tefsir, II, 95-96) 
eden kesin ve içten bir inanç; düşünce ve bağlılıktır. Dolayısıyla kurtuluşa sadece dilleriyle inandıklarını söyleyenler değil, sözlerinde duran, Allah'ın buyruğunu yerine getiren, Allah'a sayg1l, ahiret hesabina inanip bundan korkan, Hak yolunda çekilecek eziyetlere sabreden, namazlarını kılan, Allah'ın kendisine verdiği rızıktan gizli ve açık sadaka veren, kötülüğü iyilikle savan kimseler erecektir. $^{74}$

Bu noktada S. Ateş, Kur'an'ın Ehli Kitab'ın dinlerini kötüleyip onlardan dinlerini bırakmalarını istemediğini, fakat onları tevhide aykırı inançlarını terkedip Allah'a ve elçilerine inanmaya ve aşır1lıktan vazgeçmeye çağırdığını söyler: "Ey Kitap Ebli, dininizde taşkinllk etmeyin ve Allab bakkinda gerçek olmayan seyleri söylemeyin! Meryem oğlu İsa Mesih, sadece Allah'n elcisi, Onun Meryem'e atthğ kelimesi ve Ondan bir rubtur. Allab'a ve elçilerine inann; '(Allab) üctür,' demeyin. Kendi yararnıza olarak bundan vazgegin. Cü̈nkü Allah, yalmı bir tek Tanri'dr. Haşa O, çocuk sabibi olmaktan yücedir. Göklerde ve yerde olanlarn hepsi Onundur.'”5

S. Ateş'e göre, bu aşamada Hz. Muhammed'in peygamberliğini duymuş Kitap Ehlinin, onun gerçekten Hak tarafindan vahiy alan bir peygamber olduğunu, ona gelen Kur'an'in da Hakk'in vahyi olduğunu kabul etmesi, buna inanması gerekir. Şayet bunu kabul ederse o, kendi dininin hükümlerine göre amel etse de -Allah'a şirk koşmadıkça- mutlu olacaktır. Onun mutlaka dinini bırakıp Müslüman olması şart değildir. Zaten onun mesajının hak olduğunu kabul eden Kitap Ehli, kendi dini üzere gitse de son peygamberin getirdiği dinin ruhuna tabi olmuştur. Çünkü peygamberlerin misyonu, insanları sadece Hakk'a taptırmaktır. Hakk'a tapan, peygamberin mesajına uymuştur. Bütün peygamberlerin mesajları aynıdır. Herhangi bir kul Allah'a yöneliyor ve yalnız Ona kulluk ediyorsa, o peygamberin yolundadir: "Onlar ki yanlarndaki Tevrat ve Incil'de yažl bulduklarn o elçiye, o ümmi peygambere nyarlar. O (peygamber) ki, kendilerine iyiliüi emreder, kendilerini kötülükten meneder; onlara güzel seyleri helal, çirkin seyleri haram kilar; üzerlerindeki ağrrlklar, sirtlarndaki zincirleri kaldirnp atar. Ona inanan, destekleyerek ona yardim eden ve onunla beraber inen nura uyanlar; iste felaha erenler onlardir." 76

S. Ateş, bu ve benzeri ayetlerde Kitap Ehlinden dinlerini bırakmaları değil, Hz. Peygamber'in davetine engel olmayıp, ona yardımcı olmalarının istendiğini savunur. Ona göre önyargıdan ve ard düşünceden uzak olarak kendi kitaplarına bağlı kalanlar, yeni peygamberin mesajına engel olmazlar. Çünkü bu mesaj, aslında yeni olmayıp, onların kendi kitaplarında bulunan gerçeklerdir. Zira Hz. Peygamber, bu ilahi mesaj1, onun dilini anlamayan Arap milletine yeni

\footnotetext{
${ }^{4}$ Ra'd 13/19-24; Müminun 23/1-11.

5 Nisa 4/171. (Ateş, Süleyman, a.g.m., s. 12-14)

76 A'raf 7/157. (Bkz. Ateş, Süleyman, Cağdaş Tefsir, III, 397-400)
} 
bir ruh ile sunmaktadır: "Anlayasmı diye biz onu Arapsca bir Kur'an olarak indirdik." 77

S. Ateş'e göre, Kur'an'daki çağrıya uygun olarak Hz. Peygamber'e yardımcı olan, onun getirdiği nura uyan Kitap Ehli dinlerini bırakıp Müslüman olmamıs, ancak onun Hak tarafindan gelmiş kendi ellerindeki Kitab’ın içerdiği gerçeklere uygun düşen vahiyler olduğunu kabul ve itiraf etmişlerdir: "Bundan önce kendilerine Kitap verdiklerimiæ, o (Kur'an)'a inantlar. Kur'an onlara okunduğu zaman; 'Ona inandlk, o Rabbimizden gelen gerçektir. Zaten biæ, ondan önce de Müslüman (Allab'a teslim olan)lar idik,' derler. Isste sabretmelerinden ötürü onlara, mükafatlar iki kere verilir; onlar kötüliğ̈̈̈ iyilikle savarlar; kendilerine verdig̈imiz, mąlktan (yoksullara) verirler..."78

S. Ateş, burada Kur'an'a inanan Kitap Ehlinin, dinlerinden ayrıllp bir bütün olarak Müslüman olmadıklarını söyler. Ona göre dinledikleri Kur'an'ın vahiy olduğuna inanarak duygulanıp ağlayan bu iyi niyetli kimseler, $\mathrm{Hz}$. Muhammed'in peygamberliğini kabul etmekle birlikte kendi dinlerini bırakmış

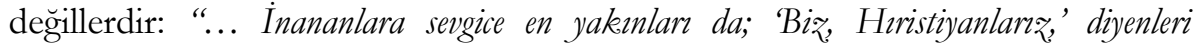
bulursun. Çünkü onlarm içlerinde keşişler ve rabipler vardir ve onlar büyülklük taslamąlar. Rasul'e indirilen (Kur'an)'ı dinledikleri zaman tanıdıklar gerçekten dolay gözlerinin yaşla

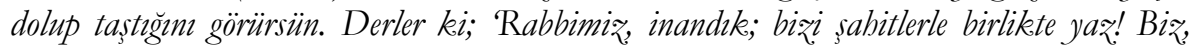
Rabbimizin, bizi iyiler arasma katmasm umarken neden Allab'a ve bize gelen gerçeğe inanamayalım?' Bu sözlerinden dolayn Allah onlara altlarndan ırmaklar akan, içinde ebedi kalacaklar cennetler verdi. Güzel hareket edenlerin mükafaatı işte budur!'79

Sonuç olarak S. Ateş, Ehli Kitab konusunda Hz. İsa'yı veya herhangi bir varlığı Allah'ın oğlu, vasıtası sayıp Ondan başka ilah edinenler dışında Allah'a şirksiz, ahirete şeksiz inanı salih amel yapan, Hz. Muhammed'in peygamberliğini ve ona gelen Kur'an'in Hakk'in vahyi olduğunu kabul etmekle birlikte Müslüman olmayıp kendi kitapları ve dinleri üzere giden kimselerin de kurtuluşa erip cennete gireceğini söyler. Ona göre bu şekilde Allah'a inanan kimse, yalnızca Allah'a ibadet ettiği için müslümandır. Onun eksikliği, Hz. Peygamber'in belirlediği ibadet yöntemini ve din kurallarını kabul etmekle birlikte, kendi dininde kalmasıdır. Bu kişi, kendi dininde kalsa bile muvahhiddir; çünkü peygambere tabi olmak, Kur'an'ın hiçbir yerinde tevhidin şartı olarak gösterilmemiştir. ${ }^{80}$

77 Yusuf $12 / 2$

78 Kasas 28/52-53. (Bkz. Ateş, Süleyman, Çă̆daş Tefsir, VI, 448-450)

79 Maide 5/82-85. (Ateş, Süleyman, a.g.m., s. 14-16)

80 Bu noktada S. Ateș'e, Hz. Peygamber'e iman edip ona uymanın imanın șartlarından biri olduğu yönünde şiddetli eleştiriler yapılmış, bunun ötesinde doğrudan kendisine yönelik 
S. Ateş, son aşamada böyle bir kimsenin en kötü ihtimalle $\mathrm{Hz}$. Peygamber'e zahiren tabi olmadığı, yani ibadeti onun öğrettiği şekilde yapmadığ1 için günahkar olacağını söyler. Ona göre Allah Teala, Kur'an'da şirk dışında her şeyi affedeceğini söylediğine göre, böyle bir kimseyi de sahip olduğu imandan dolayı affedip bağıslayacak ve cennetine sokacaktır: "Allah, kendisine ortak

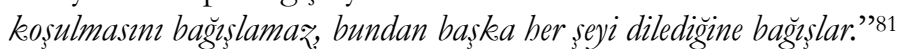

W. Cantwell Smith, meseleye daha farklı bir boyuttan bakar. Şöyle ki o, öncelikle inanc1 temel dini bir kategori olarak gören Modern Batı Medeniyeti’nin "inanma” yı dindar insanların karakteristik özelliği olarak kabul ettiğini söyler. Halbuki ona göre dini alanda bugün için önemli olan husus "inanma" (believe-belief) değil, bilakis ondan ciddi anlamda farkllllk arzeden “iman” (faith)'dır. Maalesef Kur'an'da yer almadığı halde, bütün çevirilerde İngilizce'ye ait yanlış bir çeviri olarak "iman" yerine sürekli “inanma" kavramı kullanılmıștır. Modern İngilizce’ye ait bu hatayı düzeltmede, Kur'an'daki kullanım ve İslam örneği çok yardımcı olacaktır. Zira aynı zamanda modern dünyadaki manevi krize ait bir sorun olan bu konuda, dini geleneklerin birbirinden öğreneceği çok şey vardır.

W. Cantwell Smith, Hıristiyanlar için “iman”"ın klasik ortaçağ Kilisesi’nde ve Refosmasyon döneminde son derece büyük önem arzettiğini, fakat bunun modern dönemde kaybolmaya başladığını söyler. Ona göre bunun üç sebebi vardır: Bunlardan ilki, dünyanın dini çoğulculuk içeren halihazır durumudur ki, orada bilimsel düşünceye karşı güçlü bir güven ile birbiriyle yarışan ideolojilere ait güçlü bir işleyiş hakimdir. İkinci husus, Hiristiyan yaşamında teolojinin konumudur. İslami yapıda en önemli konum şeriate aittir, buna karşın orada teolojiye/kelama o denli önem verilmemiştir. Hiristiyan Kilisesi ise, bilhassa iyilik ve kötülük konusunda Yunan düşüncesinin yoğun etkisi altında kalmıstır. Üçüncü sebep ise, “inanma” kavramının İngilizce'deki tarihi gelişim sürecidir. Şöyle ki "inanma" kelimesi, üzerinden geçen asırlar boyunca modern dini düşüncede büyük bir kafa karışıklığı ortaya çıkaracak tarzda köklü bir şekilde anlam değiştirmiştir. ${ }^{82}$

W. Cantwell Smith, burada bu sebeplerden daha ziyade üçüncüsü üzerinde durur. Ona göre Arapça'nın İslam yaşamında oynamış olduğu rolü Hıristiyan yaşamında oynayan herhangi bir dil mevcut olmamıştır. İmana dair Hiristiyan kavramlarına ait bir tarih, Almanca, Fransızca ve İngilizce’nin yanı sıra önemli ölçüde İbranice, Yunanca, Latince, vb. dillere gitmeyi gerekli kılar.

reddiye türü çalışmalar kaleme alınmıștır. (Bkz. Koçyiğit, Talat, "Cennet Müminlerin Tekelindedir”, İslami Arastrmalar, Cilt 3, Sayı 3, s. 85-94, Ankara Temmuz 1989.

81 Nisa 4/116. (Ateş, Süleyman, a.g.m., s. 23-24)

82 Smith, W. Cantwell, a.g.e, s. 266-267. 
Bu nedenle o, bunu sadece İncil; hem Eski Ahit hem de Yeni Ahit bağlamında yapmaya çalışır. Ona göre İncil'deki imana dair bir şeyi modern "inanma" kavramlarıyla tercüme etmek yanlış bir çeviridir. Nitekim klasik durum, modern zamanlarda büyük ölçüde değişmiş ve buna bağlı olarak iman nosyonu, inanma nosyonu içinde sulanmış ve çarpitılmıştır.

W. Cantwell Smith, Kur'an gibi İncil'in ve geleneksel Müslüman toplumu gibi ilk Hıristiyan Kilisesi’nin de, dünyaya ait belli bir bakış açısı oluşturduğunu, ardından da bunun içinde bizzat imana ait terimlerle algılanan ve anlatılan kişisel bir yöneliş ve kabul olarak imanın kesinlik içeren niteliğini ortaya koyduğunu söyler. Nitekim Hıristiyan Kilisesi adına konuşan kimseler, Tanrı'nın İsa'da eyleme geçen $\mathrm{O}$ olduğunu savunmuşlar; ardından da iman eylemini kişisel bir söz olarak bir tür kabul veya karşılaşma, bir sadakat sözü olarak dile getirip ortaya koymuşlardır. Buna uygun olarak Tanr1'ya iman deklerasyonu (amentü), kişinin evrenin kesin bir gerçeği olarak Tanrı'nın bilinen gerçekliğini kabul etmesiyle birlikte kendi yaşamını Ona göre düzenlemesini, kalbini ve ruhunu bütünüyle Ona verdiğini ilan etmesini ifade etmiştir. Bugün ise "inanma" kavramıla birlikte "amentü", Tanrı hakkındaki belli bir belirsizliği ifade etme noktasına gelmiştir. Öyle ki modern yaşamın bir gerçeği olarak bir kimse, artık amentüyle sadece Tanrı fikrinin onun zihni donanımının bir parçası olduğunu deklere etmektedir. Bu ikisi arasındaki fark, çok güçlü ve etkilidir.

W. Cantwell Smith, klasik șehadet ile onun modern formülasyonu arasındaki farklılı̆̆ın güçlü olmanın ötesinde, şok edici olduğunu şu şekilde gösterir: "Allab'tan baskka bir ilah olmadiğgn zannediyor ve yine Mubammed'in de Onun elçisi olduğunu düsünüyorum."

Bu aşamada W. Cantwell Smith, "believe/inanma" fiilinin İngilizce'de "zannetme" anlamına nasıl dönüştüğünü ele alır. Ona göre İngilizce "believe" kelimesinin anlamında görülen büyük değişim, asırlar boyunca ortaya çıkmış bir durum olmanın ötesinde önemli bir sonucu ve hayati bir önemi de haizdir. Şöyle ki gerçekte "sevmek, aşık olmak" anlamında olan "believe/inanmak" kelimesi, aslen tam olarak "değer vermek" anlamına gelmektedir. Bu, onun Almanca eş anlamlısı olan "belieben" kelimesinin bugün için hala ifade ettiği anlamdır. ${ }^{84}$

W. Cantwell Smith'in tespitine göre Oxford İngilizce Sözlüğünde "belief" kelimesine ait en erken kayıtlı kullanım, 12. yüzyllın sonuna ait bir vaazda; Hiristiyan kimselerin, kalplerini dünyevi menfaatlere yöneltmemeleri bağlaminda geçer; “. .. should not set their belief (on them.)” Burada Hiristiyanlar'in, maddi olan dünyaya gerçek dışı bir hayal gibi bakmaları değil, bilakis dünyevi

83 Smith, W. Cantwell, a.g.e, s. 267-269.

84 Smith, W. Cantwell, a.g.e, s. 269-270. 
olanın yeterince somut bir şekilde ortada olmakla birlikte onun saygı duyulmaya değer olmadığı ve sevgili olmaması gerektiği ima edilmektedir. Dolayısıyla kişi ona karşı zihinsel bir farkındalık içinde olmalı, fakat ona bağlılık/sadakat duymamalı, kendisine ait güvenci yani ruhunu ona adamamalıdır. Burada mesele, var olan bir şey hakkında değil; daha ziyade kişinin var olan şeye karşı tutum ve yönelişinin ne olması gerektiği hakkındadır.

W. Cantwell Smith, burada hem Tanri'nin, hem de dünyanın varolduğunun varsayıldığını, fakat önemli olanın kişinin sadakatini bunlardan hangisine vereceği olduğunu söyler. Vaazda, bunu şu ifade izler: "Aklm, kendi menfaatlerine adayan kimse." Bunu yapan kimsenin, şeytanın çocuğu olacağı ifade edilir. Bu durumda burada "Tanrı'ya inanma"nın tersi, inanmamak değil, bilakis kendini en yüksek düzeyde maddi olan şeyleri düşünmeye adamak, dolayısıyla şeytanın çocuğu olmaktır.

W. Cantwell Smith'e göre bugün için biz, vaizin şeytana inandığını söyleyebiliriz. Kelimenin bizim kullandığımız modern anlamında hiç kuşkusuz $\mathrm{o}$, şeytana inanmıştır; fakat onun kelimeye kendi yüklediği anlamda bunu ona söylemek kendisine bir hakaret ve iftira olur. $\mathrm{O}$, şeytanın varllğını yeterli düzeyde kavramıştır; fakat onun vaazında ortaya koymaya çalıştığı husus, kişinin değerini, sevgisini ve kalbini yalnızca Tanrı'ya vermesi gerektiğidir. Eğer o, bizim onun eşdeğer bir şekilde hem Tanrr'ya hem de şeytana inandığından bahsettiğimizi duyacak olsa, bizim deli-şizofren olduğumuzu düşünür. Ona göre Tanr1 ve şeytan, orada açıkça durmaktadır; fakat biz, onlar arasından birisini kendi tercihimizle seçmek zorundayız. Burada söz konusu olan husus, bizim sadakatimizi kime verdiğimizdir. Netice itibarıly bu vaazda, "bileafe/inanç" kelimesi, bugünkü "basit anlamda bir şeyin varlığını kabul etme" şeklindeki modern anlamının çok ötesinde, bizim iman olarak adlandırdığımız şeyi ve onun gerçekte "aşk, bağllık, değer verme" olarak ifade ettiği şeyi göstermektedir. ${ }^{85}$

W. Cantwell Smith'in "believe/inanma" kavramıla ilgili olarak verdiği ikinci tarihi kullanım örneği, geç Ortaçağ reformcusu Wycliffe aittir. Burada anlam, bir kimsenin inanmadığı bir şeyi baskı altında benimseyip takip ettiği bir tür zoraki "itaat etme"ye dönüşmüştür ki, teorik olarak modern anlamda bunun "inanmama"yı ifade ettiği söylenebilir. Nitekim yazar, şöyle demektedir: "They made us beleue a false law/ Onlar, bizi yanhş bir kanuna uydurdu." Ait olduğu yüzyıl göz önüne alındığında, burada onların yanlış olduğunu düşündükleri bir şeye inanmaya değil, bilakis yanlış gördükleri bir emre uyup ona hizmet etmeye zorlandıkları anlaşılır.

W. Cantwell Smith, aynı şekilde Wycliffe'in Yeni Ahid'i İngilizce'ye çevirisinde de "inanma" "y1 "itaat etme" anlamında kullandığını söyler: "I was not

85 Smith, W. Cantwell, a.g.e, s. 271-273. 
disobedient to the heavenly vision/Ben, ilabi buyruğa itaatsiəlike etmedim." $86 \mathrm{Bu}$, kişinin Tanrı'nın kendisi için dilediğini düşündüğü şeyi fillen yerine getirmede başarısızlık göstermediğini ifade eder.

W. Cantwell Smith, Wycliffe'in İncil'i İngilizce'ye çevirinde aynı anlamı ifade etmek için iki farklı kelime kullanılmasına dair değişimin açıkça ortaya çıktı̆ına işaret eder. Şöyle ki o, ilkinde "bilefe" kelimesini kullanırken, daha sonra onun yerine pek çok yerde yeni bir kelime olan "faith/iman" kelimesine yer vermiştir. Bu, Latince "fides" kelimesinin Fransızca'dan İngilizce'ye geçen şekli olarak daha sonra kullanıma geçmiştir. Bu geçiş, Oxford Sözlügü’nde şu şekilde ortaya konur:

“Belief” kelimesi, geçmişte bugün için yaygın bir şekilde "faith/iman” olarak dile getirdiğimiz şeyi ifade etmek için kullanılan önceki döneme ait bir kelimedir. İman, asli olarak İngilizce'de (eski Fransızca'da olduğu gibi) şunu ifade eder: "Söz veya görev olarak uymakla yükümlü olduğu kimseye; onun sözüne veya bizzat görevin kendisine gösterilen sadakat." "İmanını korumak, imanı bozulmak" ve onun türevleri "imanlı, imansız" bu anlamdadır. Burada "belief/inanc"a referans yoktur. Bu noktada "faith/iman", "bağlllık, sadakat" ile eşdeğer olmuştur. Etimolojik olarak Latince "fides" kelimesinin karşıllı̆̆ olan ve eski Fransızca'da "fei, feith" ile ifade edilen "faith" kelimesi, 14. yüzyılda tercümelerde "iman"1 ifade etmek için kullanılmaya başlanmış, zaman içinde bilhassa teolojik dilde neredeyse bütünüyle "belief'in yerini almıştır. Bu aşamada "belief”, büyük ölçüde sadece entelektüel çalışma veya ifadelerde kullanılır olmuştur. Bu nedenle artık "Tanrı'ya inanmak (belief)", "Tanrı'ya iman etmek (faith)" kadar anlam ifade etmemektedir..."87

W. Cantwell Smith, imana dair hususların "belief" kelimesiyle değil de, "faith" kelimesiyle ifade edilmesine dair sürecin 1611'e kadar büyük ölçüde tamamlandığını söyler. Zira bu yılda yapılan Kral James'in İncil versiyonunda "faith" kelimesi 233 defa geçerken, "belief" kelimesi sadece bir defa geçmektedir.

W. Cantwell Smith, bu aşamada önemli bir probleme dikkat çeker. Şöyle ki Yunanca ve Arapça'da mevcut olmakla birlikte İngilizce'de "faith" ile ilgili bir fiil yoktur. Bu nedenle çevirmenler, "believe" kelimesini daha önce ifade ettiği "sevmek, değer vermek, haturlamak ve (kavramsal olarak) tanyzp kabul etmek" gibi anlamlarda bir fiil olarak korumuşlardır. Ona göre artık bu geçiş sürecinin "faith" kelimesine ait bir fiil ile tamamlanma vakti gelmiştir. Zira resmi versiyonundan üç buçuk asır sonra "faith" kelimesi, henüz hala asli dini anlamını kaybetmemiș olmakla birlikte, "believe" ve "belief" kelimeleri kaybetmiştir. Dolayısıyla bugün için biz, "belief/believe" kelimesini dini birer

86 The New Testament, The Acts Apostles, 26:19.

87 Oxford İngilizce Sözlüğü, "Belief” md. 
terim olarak kullanmayı terk ettik; çünkü artık onlar manevi önem arzeden bir şeyi ifade etmemektedir. O halde bizler, bugün için "faith" kelimesinin ifade ettiği manayı yeniden keşfetmek, ardından bir fiil olarak iman sahibi olmanın ifade ettiği manayı yeniden ortaya çıkarmak durumundayız..$^{88}$

W. Cantwell Smith'e göre "belief" kelimesinin "iman etme"den "zannetme" anlamına kadar süren etkileyici geçişin gözlemlenebilir üç aşaması mevcuttur. Bunlardan ilki, bir kimseye inanmaktan bir şeye inanmaya doğru fiilin nesnesi bağlamında olmuştur. Bu nesne, daima bir kişi olarak başlar; yine daima bir öneri olarak sona erer. Diğer bir deyişle o, kişiler arası bir ilişkiden, teorik bir doğrulamaya doğru bir geçişi; diğerleriyle ilişki içindeki kişisel bir eylemden akla ait bir tutuma doğru geçişi ifade etmiştir.

İkinci geçiş, fililin yapısında olmuştur. Bu, varoluşsal olandan betimleyici olana doğru bir değişimdir. Şöyle ki; "Ben, inanıyorum”dan, "o, inanıyor" veya "onlar inaniyor"a doğru bir geçiş. Bunlardan ilki kişisel bir kabul ve onayı içerirken, sonuncusu basit anlamda bir gerçeği dile getirmektedir.

Üçüncü geçiş ise, doğru olan bir şeye inanmaktan tam bir tarafsızlığa doğru olmuştur. Buna göre bir kimse aynı oranda doğru olana da, yanlış olana da, kesin olmayana da inanabilir. ${ }^{89}$

W. Cantwell Smith, bu geçişe ait devinimin günümüze kadar hızla devam ettiğini söyler. Öyle ki yirminci yüzyılın ortasında ve sonraki kısmında pek çok konuşmac1 ve yazar, "belief" ve "believe" kelimelerini belli kontekslerde, bilinçsizce de olsa, bir fikrin yanlış olduğunu veya en azından kuşkulu olduğunu benimsediğini ortaya koyan bir tercihi ima edecek şekilde kullanmaktadır. O, bu geçişi şu üç önermeyle ortaya koyar:

1. O, A’nın B olduğunu bilmekte/kabul etmektedir (recognize).

2. O, A'nın B olduğu görüşündedir (opinion).

3. $\mathrm{O}$, A'nın B olduğunu düşünmekte/sanmaktadır (imagine).

Burada, ilk önerme onun doğru olduğunu ifade etmekte, sonuncu onun yanlış olduğunu göstermekte, ortada ise bir duruş benimsenmemektedir. Ona göre, "believe" kelimesi, yüzyıllardır süregelen İngilizce kullanımında; (başlamış olduğu) birinci durumdan (18. yüzyll öncesi ve sonrasındaki) ikinci durum boyunca (günümüzde yeni başlamış olan) üçüncü duruma doğru bir yöneliş içinde olmuştur. ${ }^{90}$

88 Smith, W. Cantwell, a.g.e, s. 273-274.

89 Smith, W. Cantwell, a.g.e, s. 274-276.

90 Smith, W. Cantwell, a.g.e, s. 276. 
W. Cantwell Smith'e göre, günümüzde İngilizce konuşulan dünyada seküler insanlarla dindar olanlar arasındaki farklardan biri, "believe" kelimesinin her biri için farklı şeyler ifade etmesidir. Bununla birlikte dindar kimseler, hiç kuşkusuz seküler olanlara göre daha az oranda olmakla birlikte, kaçınılmaz olarak bu gelişmelere iştirak etmiş ve kesinlikle onlardan etkilenmişlerdir.

W. Cantwell Smith'e göre, "Ben, Tanr1'ya inanıorum” ifadesi, geçmişte şu anlamda kullanılırdı: "Tanr oradadır"; bundan ötürü ben kalbimi ve gönlümü Ona veriyorum. $O$, bana varlk kazandird; bu nedenle ben yasamım, lütfuna güvenerek. Onun tarafindan yönetilmeye adiyorum." Bugün ise, aynı ifade şu manada anlaş1labilmektedir: "Tanrı'nn orada var olup olmadğg bakekinda ciddi bir soru mevcuttur; ben, kendi fikrimin Onu onaylama yönünde olduğunu deklere ediyorum; ayn sekilde ben, Onun varolduğuna bülemediyorum." Ve ahlaki bir onay veya yaşam tavr1 olarak; "Ben, kendi kararma güveniyorum."

W. Cantwell Smith, bugünlerde bazılarının teslimiyet, güven ve söz anlamında Tanrr'ya imanın, öncesinde ona inanmayı gerektirdiğini söylediklerini belirtir. Bu durumda karşımıza şu soru çıkmaktadır: "Bir kimse imana sahip değgilse, böyle bir inanc keüfür değil midir; sayet o iman sahibi değilse, bu takdirde inanc önemsiz değil midir?’ Bu oldukça dramatik ve açık-seçik olmakla birlikte bütünüyle doğru değildir. Zira ona göre inançlar da önemlidir; özellikle de akli yaşama, sebeplere sarılmaya ve dini yaşamı, hatta imanı içeren dünyaya dair ilmi anlayışa karşı sorumluluk taşıyan ilim adamları için. ${ }^{91}$

W. Cantwell Smith' göre, Klasik İslami bakış açısı ve klasik Hıristiyan bakış açısı için hayati olan soru imana dairdi; modern Batı kültüründe ise dikkat, ondan tamamen farklı olan inanç sorusuna doğru yönelmiştir. Nihai, acil, kesin insan sorusu, Hakk ile olan bütüncül, kişisel, pozitif ilişki anlamında hala imandır; buna nazaran diğer bütün hususlar ikincildir. Bununla birlikte son dönemlerdeki inanca dair Batı vurgusu, yanlış yere yapılmış ve altüst edilmiş olma ihtimaliyle birlikte hiç de tesadüfi ve aptalca değildir. Şöyle ki yukarıda, İngilizce'de klasik anlamdaki "believing"den modern anlamdaki "believe"e doğru; yani imandan inanca doğru bir geçişten bahsedilmişti. Bu noktada klasik anlamda geçmişte benimsenen dini inançlar, açık bir şekilde dile getirilmemiş; çünkü onlar, zaten varsayılmışlardır. Modern dünyaya ait dini krizler, işte tam da bu varsayımlardan ortaya çıkmaktadır.

W. Cantwell Smith, Müslüman ve Hiristiyan dünya bakışları, içinde düşüncenin gerçekleştĭgi, imanın ve sadakatsizliğin kavranıp anlaşılır hale geldiği kavramsal çatılar, ilmi sistemler ve örnek modellerdir. Ona göre bu uyumlu düşünce sistemleri, insanın karşısına geçip baktığı şeyler değil, bilakis sayesinde dünyayı, kendisini ve komşularını algılayıp anlamlandırdığı hususlardır. Meseleye

91 Smith, W. Cantwell, a.g.e, s. 276-277. 
Batı Hıristiyanlı̆̆ açısından bakılacak olursa, varolduğu farzedilen ve mevcut üst yapıya temel oluşturan şeyin, artık daha fazla Batı insanının imanının, bütün dini ve sosyal yaşantısının kendisine dayanacağı temel bir zemin olarak hizmet edemeyeceği açığa çıkmıştır. Bu gerçekleştiğinde Batı insanı, farkında olmadan sahip olduğu dini kategorileri değiştirmiştir. Nitekim o, dikkatini imana dair anlam dolu sorudan modern inanç sorusuna; yani kişinin belli bir dini sistemde ne yaptığ1 sorusundan, onun belli bir dini sisteme sahip olup olmadığı sorusuna doğru çevirmiştir. ${ }^{92}$

W. Cantwell Smith'e göre, neticede bugün için bir kimsenin kendisine dini sembol sistem olarak neyi seçtiği ve yoluna ne olarak devam ettiği önemli olmakla birlikte, bundan daha önemli olan husus, onun tercih ettiği bu dini sistem içinde ne yaptı̆̆, hangi cevapları ürettiği; yani Kur'an'da güzel ifade edildiği ve bir zamanlar Kilise tarafindan dile getirildiği gibi imana; yani (ilahi olana kişisel) karşılık vermeye ait kategoridir. Aynı şekilde gerek kendimiz, gerekse diğerleri için de önemli olan husus, hangi dini sisteme inandığımız veya inanmamı gerektiği değil, bilakis işletmek için hangi dini sistemi seçtiğimiz ve onun gerçekte o olup olmadığını bilip bilmediğimizdir.

W. Cantwell Smith, bütün bu bilgiler 1şı̆̆ında şu sonuca ulaşır: Müslümanların inançları, gayet iyi bilindiği üzere Hıristiyanların inançlarından büyük ölçüde farklılık arzetmekle birlikte, onların imanları sanılandan çok daha fazla olarak birbiriyle belli bir noktada birleşmektedir. ${ }^{93}$

W. Cantwell Smith, kendisinin bu noktaya gelmesinde Muhammed İkbal ile Celaleddin Rumi gibi sufilerin görüşlerinin büyük etkisi olduğunu ifade eder. Şöyle ki bu sufiler, ona günlük sıradan formların ilahi olana götüren işaretler olabileceğini öğretmişlerdir. Buna göre taşıdıkları farklılıklara rağmen bu günlük sıradan formlar, insanlara kendilerinin ilahi olanla buluşmalarına aracilık eden birer kanal olarak hizmet etmişlerdir; dolayısıyla iman için yalnızca bir tek değil, birbirinden farklı değişik dini yapılar söz konusudur.

W. Cantwell Smith, bir ilim adamı olarak kendisinin inançları; yani farklı dini sistemleri iman olarak değil, fakat imanın arabulucuları olarak görme fikrine hoş bakar. Öyle ki atalarımız, kendilerini Tanrı'ya ulaştıran yollarını bu dini sistemler sayesinde bulmuşlar, bunun da ötesinde Tanr1 (Gerçek, Hakk), farklı toplumlardaki insanların yaşamlarına giden Kendi yolunu bu dini sistemlere ait yapılar içinde gerçekleştirmiştir. Bu noktada inanç, iman olmamıştır. Fakat Tanrı, inançları kullanmış; insanların imanlarının ve yaşamlarının içinde

\footnotetext{
Smith, W. Cantwell, a.g.e, s. 277-279.

Smith, W. Cantwell, a.g.e, s. 279-280.
} 
şekillendiği bir kalıp olarak birden fazla türde, ama makul ve samimi olan inançları kullanmayı dilemiş olabilir. ${ }^{94}$

W. Cantwell Smith, bu noktada kendisini çok etkilediğini ifade ettiği teolojik/kelami bir ifade tarzına atıfta bulunur. Buna göre kelamda, kişinin imanını nasıl dile getirmesi gerektiğine dair şu iki önerme tartışılmıştır:

أنا مؤمنٌ إن شاء اللهّ/Ben, Allah dilerse müminim.”

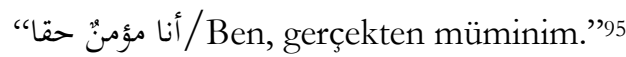

W. Cantwell Smith, burada ele aldığ1 meseleyi söz konusu kelami önermeleri kendisine özgü bir şekilde yepyeni birer ifade şekline dönüştürerek bitirir:

“ انا مؤمنُ إن شاء الله /Ben, Allah dilerse müminim.”

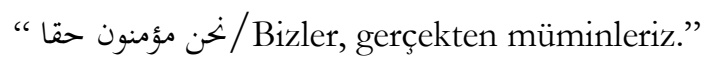

O, burada kendi şahsi durumuyla ilgili olarak çekimser kalmayı ve konuyu Tanrı'nın ellerine birakmayı tercih ederken, Müslüman ve Hiristiyan olarak her iki toplumun da iman sahibi olduğu kanaatini dile getirip vurgular. Ona göre bizim Tanrı'yla olan ilişkimizi kavramsallaştırdığımı, formüle ettiğimiz, ahlakileştirdiğimiz sistemler birbirinden farklıdır; fakat bu ilişkinin bizatihi kendisi, 1srarla vurgular ki, her iki durumda da mevcut ve kesindir.

W. Cantwell Smith, bizim inançlarımızın farklılık arzettiğini ve bunun önemli olduğunu söyler. Fakat ona göre bu, nihai anlamda önemli değildir; çünkü Tanrı'nın bizatihi son noktada ilgilendiği şey bu değildir. Evrensel olan husus, imandır. $\mathrm{O}$, her iki kesimin de imana sahip olduğunu savunur ve şöyle bitirir: "Ben, iman sabibi bir kimseyim ve umarm ki Tanr bunu bana lutfedecektir; bizler ise, gerçekten ama gerçekten iman sabibi kimseleri2." 96

\section{SONUÇ}

Görüldüğü üzere Süleyman Ateş ve W. Cantwell Smith, birbirlerinden oldukça farklı yol ve yöntemler izlemekle birlikte, neticede birbirlerine oldukça yakın sonuçlara ulaşmışlardır. Her ikisinin de öncelikli olarak üzerinde uzlaştıkları husus, bilhassa bugün için geleneksel Hiristiyan ve İslam anlayışlarının birbirlerini anlamada büyük ölçüde yetersiz kaldıklarıdır. Bu

94 Smith, W. Cantwell, a.g.e, s. 280.

95 Bunlardan ilkinde kişi, iman sahibi olduğunu ummakta, fakat bunun Tanrı'nın kararı ve lütfuyla olacağını bilmektedir. İkincisinde ise o, kendisinin iman sahibi olduğunu ifade etmekte ve bu konuda Tanrı'nın lütfunun kendisine ulaştığına dair inancını kesin bir dille ortaya koymaktadir.

96 Smith, W. Cantwell, a.g.e, s. 280-281. 
noktada onlar, kendi geleneklerini eleştirmek suretiyle günümüz için daha makul ve mutedil bir yaklaşım tarzı geliştirmeye çalışmaktadırlar.

Tarihi gelişim süreci itibarılyla Süleyman Ateş, Ehli Kitab ile İslam'ın birbirine göre konumunu Kur'an çerçevesinde ele alır. Ona göre özünde aynı olan bu dini geleneklerin hepsinin ortak adi İslam'dir. Onlar, birbirlerini neshedip ortadan kaldıran değil, bilakis destekleyip bütünleyen bir ilişki tarzı içinde olmuşlardır. W. Cantwell Smith ise, meseleye ilahi çerçevede değil de, beşeri tarzda ve akıl merkezli olarak yaklaşır. Bununla birlikte o da, benzer şekilde bu dini geleneklerin tarihi oluşum ve gelişim süreçleri içinde birbirlerini bütünlediklerini, dolayısıyla birbirinden ayrı düşünülemeyeceklerini söyler. Ona göre bunları, birbirinden müstakil ayrı ayrı yapılar olarak değil, bir bütünün farklı yüzleri şeklinde ele alıp incelemek gerekmektedir.

S. Ateş, İslam geleneğinde düşünülenin aksine Tevrat ve İncil'in Kur’an tarafindan bütünüyle neshedilip hükümsüz birakılmak bir yana onun tarafindan onaylanıp tasdik edildiğini, dolayısıyla onların bugün itibarıyla kendilerine gereğince uyanları hala daha kurtuluşa erdirme potansiyeline sahip hak birer kitap olduklarını söyler. W.C. Smith ise, teorik anlamda kendisi açık bir şekilde ifade etmese de, bugün için pek çok Batılı ilim adamının Kur'an'ın ilahi vahye dayalı bir kitap olduğunu kabul etme noktasına geldiğini söyler. Bunun ötesinde ona göre zaten Kur'an, Müslümanlar tarafindan kendisinden ilham alınmak suretiyle üzerinde inşa edilen pek çok parlak İslam medeniyetiyle kendisinin hak olduğunu tarihi olarak gerçekleştirmiş durumdadır. Bu noktada onun arzuladığı şey, Kur'an'ın kutsal bir kitap olduğunu ilahi yönden olduğu kadar, beşeri ve akli yönden de ortaya koyacak rasyonel yaklaşım tarzlarının geliştirilmesidir.

S. Ateş, kurtuluş konusunda din farkı gözetmeksizin herkes için genel ve evrensel olduğunu ifade ettiği üç şart ileri sürmektedir; Allah'a şirksiz, ahirete şeksiz inanmak ve salih amel yapmak. Bu noktada o, Hz. Muhammed'in peygamberliğini kabul etmenin şart olmakla birlikte, onun şeriatine göre yaşamanın zorunlu olmadığını söyler. Bu durumda kişinin en fazla günahkar olacağını, fakat amel imandan bir cüz olmadığ için bunun kurtuluşa mani olmayacağını ileri sürer. $\mathrm{Bu}$ noktada $\mathrm{o}$, teslisi reddettiği için geleneksel Hiristiyanlar tarafindan, Hz. Peygamber'in konumunu ve sünnetini hafife aldığ1 için de Müslümanlar tarafindan eleştirilip reddedilmiştir. Bununla birlikte onun, teorik düzeyde de olsa, cennetin Müslümanların tekelinde olmadığını ifade etmek suretiyle kurtuluş konusunda herkese açık evrensel bir bakış açısı ortaya koyduğunu kabul etmek gerekir.

W. Cantwell Smith ise, kurtuluş konusunda farklı bir yol izleyerek diğerinden daha geniş bir bakış açısı ortaya koyar. Ona göre Hıristiyanlar, kendilerini Tanrı'ya adadıkları için en azından kelime anlamında Müslüman oldukları gibi, Müslümanlar da Hz. İsa'ya inandıkları için zaten Hıristiyan'dır. $\mathrm{Bu}$ noktada önemli olan husus, hangi dini sisteme inanıldığından ziyade bu 
sistem içinde gerçek anlamda Tanrı'ya imana ulaşılıp ulaşılmadığıdır. Şayet bu başarılmışsa, bu durumda kurtuluş hangi dine mensup olursa olsun bütün herkes için mümkündür. Ona göre hem Hiristiyanlar, hem de Müslümanlar gerçek anlamda iman sahibi olup, kurtuluşa ereceklerdir. Muhtemelen onun tarafindan ortaya konan bu yaklaşım tarzı, içinde Hz. İsa'nın uluhiyeti ve teslis inanc1 yer almadığı için Kilise tarafından reddedilmiş, İslam şeriatine yer verilmediği için de Müslümanlar tarafından kabul görmemiştir. Bununla birlikte sonuçta o da, bir ilim adamı olarak kendisi açısından makul ve evrensel bir kurtuluş formülü geliştirmiştir.

Netice itibarıyla bu iki ilim adamı, kendi geleneklerini karşılarına almak pahasına ortaya çıkıp görüşlerini cesaretle ortaya koymuşlardır. Onlar, günümüzün iyice küçülen global dünyasında iç içe yaşayan farklı din mensubu kimseleri, tarih boyunca bedelini ağır bir şekilde ödedikleri birbirini dışlama tavrını bir yana bırakıp birbirlerini doğru bir şekilde anlamaya davet etmektedirler. Bu aşamada onlar tarafindan ortaya konan herkese açık evrensel kurtuluș reçetelerinin, bu iki kesim tarafından hemen kabul görmesini beklemek mümkün değildir. Bilakis bunların, belli ölçüde kafa karıştırıcı oldukları için her iki kesimi de büyük ölçüde rahatsız edeceği açıktır.

Bununla birlikte şahsen biz, hak din olduğuna inandığımız İslam dini mensubu bir kimse olarak Batı'da yaşayan din kardeşlerimizin her gün karşı karşıya oldukları sorunları belli ölçüde giderme adına bu tür farklı görüşleri duyup öğrenmekten kaçma veya görmezlikten gelme şansı veya lüksüne sahip olmadığımız kanaatindeyiz. Bu noktada önemli olan husus, farklı dinden kimselerin birbirleriyle çatışmayı bırakıp aynı masa etrafında oturup birlikte konuşabilmeleridir. Bu aşamada herkes kendi görüşlerini ve delillerini ortaya koyacak, neticede haklı olan veya bunu ikna edici bir şekilde ortaya koyabilen kimse ve kesimler ön plana çıkacaktır.

$\mathrm{Bu}$ noktada herkesin ille de aynı görüşte veya dinde birleşmesini beklemek doğru da, mümkün de değildir. Bununla birlikte bu gibi ciddi ve ilmi çabalar sayesinde, farklı din mensupları arasında, en azından birbirlerinin kırmızı çizgilerini öğrenip bunları aşmamaya özen göstererek karşılıklı saygıya dayalı bir barış ortamı içinde birlikte yaşamanın önü açılabilir. Aksi takdirde nefislerine yenik düşerek birbirleriyle Tanrı adına kavga edip çatışmayı sürdüren dini kesimler, günümüzün inançtan yoksun maddeci hayat felsefesi karşısında kendilerini perişan ettikleri gibi temsil ettikleri dinleri de küçük düşürmeye, böylece şeytanın ekmeğine yağ sürmeye devam edeceklerdir. 


\section{Kaynakça}

Akgündüz, Ahmet, Çan'dan Minare'ye Büyük İtiraf, İstanbul 2010.

Ateş, Süleyman, "Cennet Kimsenin Tekelinde Değildir", İslami Araștrmalar, Cilt

3, Say1 1, s. 7-24, Ankara Ocak 1989.

Ateş, Süleyman, Yüce Kur'an’in Çağdaş Tefsiri, İstanbul 1991.

el-Buharî, Muhammed b. Ali, el-Camiu's-Sabih, İstanbul tz.

Cragg, Kenneth, The Call of The Minaret, New York 1956.

Cragg, Kenneth, Sandals at The Mosque; Londra-New York 1958.

Erkal, Mehmet, "Cizye”, Diyanet İslam Ansiklopedisi, İstanbul 1993.

Fazlurrahman, Probhecy in Islam: Philosophy and Orthodoxy, Londra-New York, 1958.

Gibb, Hamilton A. R., "Pre-Islamic Monotheism in Arabia", Harvard Theological Review, 55, 1962.

Hamidullah, Muhammed, İslâm Peygamberi, (Çev: Salih Tuğ), Ankara 2003.

Http://video.haber7.com/play.video.php?id=5765

Http://webtv.hurriyet.com.tr/2/18527/0/1/italya-kilise-de-ilk-escinselevlilik.aspx.

İbnü'l-Esir, Üsdü'l-Gabe fi Marifeti's-Sababe, Beyrut tz.

İbn Hişam, Ebu Muhammed, es-Siratü'n-Nebeviyye, Beyrut tz.

İbn Kesir, İsmail b. Kesir, Tefsiru'l-Kur'ani'-Azim, İstanbul 1985.

İbn Sa'd, Ebu Abdullah, et-Tabakatü'l-Kübra, Beyrut tz.

Koçyiğit, Talat, "Cennet Müminlerin Tekelindedir”, İslami Arastırmalar, Cilt 3, Sayı 3, s. 85-94, Ankara Temmuz 1989.

el-Kurtubi, Ebu Abdullah, el-Cami' li Abkeami'l-Kur'an, Beyrut 1965.

el-Müslim, Müslim b. el-Haccac, el-Camiu's-Sahih, İstanbul 1981.

Oxford İngilizce Sözlüğü, "Belief” md.

Osteen, Joel, “The Meat of His Pork Message”, YouTube Videos.

es-Serahsi, Ebu Bekr, el-Mebsut, Beyrut tz.

Smith, Wilfred Cantwell, On Understanding Islam (Selected Studies), The Hague, The Netherlands 1981. 
Sönmez, Zekiye, İslam’n Ortaya Çktığ Dönemde Arap Yarmadasında Hiristiyanlık, Ankara 2012.

et-Taberi, Muhammed b. Cerir, Camiu'l-Beyan an Te'vili Ayi'l-Kur'an, Kahire 1955-1969.

Vitray-Meyerovitch, Eva de, İslam’ın Güler Yü̊ü, (Çev. Cemal Aydın), İstanbul 1999. 